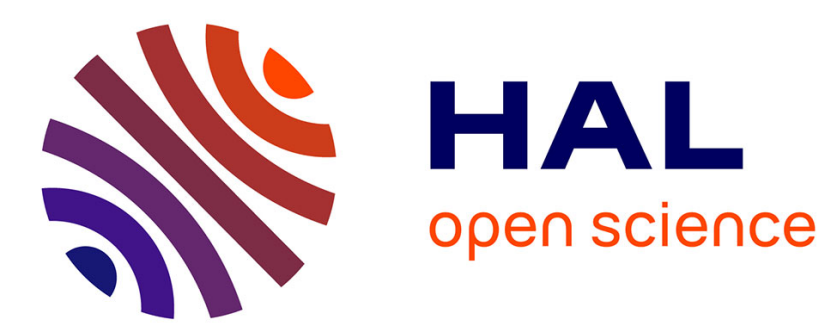

\title{
Energy, exergy and economic analyses of new coal-fired cogeneration hybrid plant with wind energy resource
}

\author{
Z.X. Li, M.A. Ehyaei, A. Ahmadi, D.H. Jamali, R. Kumar, Stéphane
}

Abanades

\section{- To cite this version:}

Z.X. Li, M.A. Ehyaei, A. Ahmadi, D.H. Jamali, R. Kumar, et al.. Energy, exergy and economic analyses of new coal-fired cogeneration hybrid plant with wind energy resource. Journal of Cleaner Production, 2020, 269, pp.122331. 10.1016/j.jclepro.2020.122331 . hal-02931726

\section{HAL Id: hal-02931726 \\ https://hal.science/hal-02931726}

Submitted on 5 Nov 2020

HAL is a multi-disciplinary open access archive for the deposit and dissemination of scientific research documents, whether they are published or not. The documents may come from teaching and research institutions in France or abroad, or from public or private research centers.
L'archive ouverte pluridisciplinaire HAL, est destinée au dépôt et à la diffusion de documents scientifiques de niveau recherche, publiés ou non, émanant des établissements d'enseignement et de recherche français ou étrangers, des laboratoires publics ou privés. 


\section{Journal Pre-proof}

Energy, exergy and economic analyses of new coal-fired cogeneration hybrid plant with wind energy resource

Z.X. Li, M.A. Ehyaei, A. Ahmadi, D.H. Jamali, R. Kumar, Stéphane Abanades

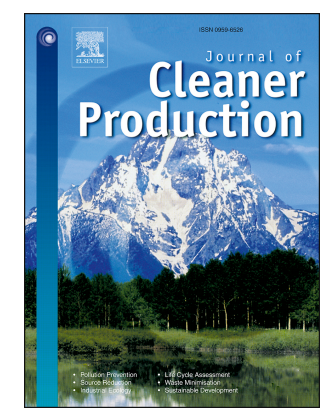

PII:

S0959-6526(20)32378-7

DOI:

https://doi.org/10.1016/j.jclepro.2020.122331

Reference: JCLP 122331

To appear in: Journal of Cleaner Production

Received Date: 16 August 2019

Revised Date: 15 May 2020

Accepted Date: 15 May 2020

Please cite this article as: Li ZX, Ehyaei MA, Ahmadi A, Jamali DH, Kumar R, Abanades Sté, Energy, exergy and economic analyses of new coal-fired cogeneration hybrid plant with wind energy resource, Journal of Cleaner Production (2020), doi: https://doi.org/10.1016/j.jclepro.2020.122331.

This is a PDF file of an article that has undergone enhancements after acceptance, such as the addition of a cover page and metadata, and formatting for readability, but it is not yet the definitive version of record. This version will undergo additional copyediting, typesetting and review before it is published in its final form, but we are providing this version to give early visibility of the article. Please note that, during the production process, errors may be discovered which could affect the content, and all legal disclaimers that apply to the journal pertain.

(C) 2020 Published by Elsevier Ltd. 
1. School of Engineering, Ocean University of China, Tsingdao 266100, China

2.School of Mechanical, Materials, Mechatronic and Biomedical Engineering, University of Wollongong, Wollongong, NSW 2522, Australia

3. Department of Mechanical Engineering, Pardis Branch, Islamic Azad University, Pardis New City, Iran

4. Iran University of Science and Technology, School of New Technologies, Department of Energy Systems Engineering, Iran

5. School of Environment, College of Engineering, University of Tehran, Tehran, Iran

6. School of Mechanical Engineering, Lovely Professional University, Phagwara, Punjab, India

7. Processes, Materials, and Solar Energy Laboratory, PROMES-CNRS, 7 Rue du Four Solaire, 66120 FontRomeu, France

Abstract. A novel configuration of a coal-fired cogeneration plant is proposed in this paper. This novel system is composed of combustion chamber, Rankine cycle, absorption chiller, alkaline electrolyzer, and methanation plant. In the proposed configuration, the heat of exhaust gas from the combustion chamber can be used in a Rankine cycle to produce electricity. The heat of exhaust gas also powers the absorption chiller to provide cooling. The exhaust gas flows through a sulfur extraction unit to separate sulfur from $\mathrm{CO}_{2}$ gas. To supply electrical power, wind turbines alongside the Rankine cycle are considered. A part of the produced electricity from both the Rankine cycle and the wind turbines can be used by an alkaline electrolyzer to produce hydrogen and oxygen. The $\mathrm{CO}_{2}$ gas from sulfur unit and 
hydrogen gas $\left(\mathrm{H}_{2}\right)$ provided by the electrolyzer can be delivered to a methanation unit to produce syngas $\left(\mathrm{CH}_{4}\right)$ for different applications. The oxygen from the electrolyzer is injected into the combustion chamber to improve the combustion process. Results show that by using 80 units of $1 \mathrm{MW}$ Nordic wind turbine to generate electricity, all of the $\mathrm{CO}_{2}$ in the exhaust gas is converted to syngas. The whole system energy and exergy efficiencies are equal to $16.6 \%$ and $16.2 \%$. The highest and lowest energy efficiencies of $85 \%$ and $30.1 \%$ are related to compressor and steam power plants. The energy and exergy efficiencies of the wind turbine are $30.7 \%$ and $11.9 \%$. The system can produce $40920.4 \mathrm{MWh}$ of electricity and $180.5 \mathrm{MWh}$ of cooling. As $\mathrm{CO}_{2}$ is consumed to produce syngas, the proposed system is capable of avoiding a significant amount of 2776 t $\mathrm{CO}_{2}$ emissions while producing $1009.4 \mathrm{t}$ syngas annually. Based on economic analysis, the payback period of the system is $11.2 \mathrm{y}$, and internal rate of return is found to be $10 \%$, which can prove the viability of the proposed configuration.

Keywords: Energy, Exergy, Power to gas, Methanation, Rankine cycle, Wind turbine

\section{Introduction}

The worldwide energy demand for electricity generation is growing steadily. Fossil fuel is playing a major role to fulfill this demand. The excessive use of fossil fuel within the current energy infrastructure is causing natural disasters and health issues. The continuous $\mathrm{CO}_{2}$ emissions are at least partially responsible for global warming (Atabi et al., 2014; Mozafari and Ehyaei, 2012). In 2016, coal-based power plants and other carbon-intensive sectors for electricity and heat generation contributed to $42 \%$ of global emissions (Shirmohammadi et al., 2018). By 2040, it is expected that global energy-related carbon dioxide emissions may reach around 43.2 billion t (Conti et al., 2016). These considerable global emissions are forcing policymakers to adopt an eco-friendly and sustainable alternative option for power generation in the entire world. Renewable Energy (RE) sources may play a key role to achieve this target because of their environmentally-friendly nature. Solar and wind energy resources are playing a 
crucial role in electricity generation while shifting fossil fuel consumption towards cleaner energy sources (Dorotić et al., 2019; Shaygan et al., 2019). According to an estimate, RE sources contribution to power supply was estimated to be more than 30\% during 2010-2015 (Bellocchi et al., 2019). The impact of implementing RE sources in the heat and transportation sector is attracting more attention due to the dependency of this sector on fossil fuels (Dorotić et al., 2019). The European Commission target included 20\% of RE contribution in its 2021 energy roadmap (Roadmap, 2011). Amongst various RE resources, the wind power promises a great potential in electricity generation and it reached up to 539 GW in 2017 globally. Hydrogen is also a promising viable option to replace fossil fuels for reliable power generation and for being used as vehicles fuel. The main advantage of hydrogen as an energy carrier is its flexible conversion into other energy forms in an efficient way in comparison to fossil fuels (Castaneda et al., 2013; Li et al., 2019).

Due to rapid growth in gas-fired based electricity generation, the integration of electricity, district heating and RE resources are attracting research towards clean energy generation in recent years. Researchers are also focusing on wind-solar hybrid power plants and trying to integrate different energy carriers in an energy hub (Gholizadeh et al., 2019; Yang et al., 2018). It has been proven that multi-products system can significantly enhance the performance of the system in comparison to singleproduct system (Jamali and Noorpoor, 2019; Li et al., 2019). The rules and regulations set by international organizations to mitigate climate changes are forcing the nations to promote clean energy (Lisbona et al., 2018).

The search for innovative technologies framework for sustainable development is getting more importance in the energy sector in recent years. Power-to-gas (PtG) technique is a viable option for the storage of surplus electricity generated by RE sources. It is a rising technology in the future energy sector to compete with existing technologies used for power generation (Walker et al., 2017; Weidner et al., 2018). In PtG, gas fuel is produced and long-term stored using electricity. The main advantage of this 
technology is that the surplus electricity is absorbed from the grid. Wind and solar power have great potential for the long term PtG operation (Guandalini et al., 2017). The use of an electrolyzer provides hydrogen from the electricity (Kreuter and Hofmann, 1998). There are various types of electrolysis technologies such as high-temperature electrolysis, alkaline water electrolysis, and polymer electrolyte electrolysis that are developed worldwide at large, laboratory and small scale (Buttler and Spliethoff, 2018). The separated pure hydrogen along with captured $\mathrm{CO}_{2}$ can be used directly in the methanation process to produce Synthetic Natural Gas (SNG) (Ghaib and Ben-Fares, 2018). This gas can be used as a carbon-neutral fuel in the transport sector to reduce the level of $\mathrm{CO}_{2}$ emissions. Another research was carried out to compare different catalysts usually used for $\mathrm{CO}_{2}$ methanation. The catalysts were tested to determine the most suitable operating temperature and pressure, which turned out to be $673 \mathrm{~K}$ and 10 bar (García-García et al., 2018).

PtG systems proved to be suitable for sustainable energy storage using renewable energy sources (Lewandowska-Bernat and Desideri, 2018; Llera et al., 2018). Several studies on PtG plant have also been performed in recent years. PtG projects in Europe have been reviewed and discussed in detail (Wulf et al., 2018). PtG and Power to liquid (PtL) were identified as promising concepts to avoid source fluctuations when renewable energies are considered as primary energy sources. The $\mathrm{CO}_{2}$ reduction trends were predicted in the case of using these technologies, and biomass gasification with subsequent hydrogenation could have great performance in integration with PtG systems (Bellocchi et al., 2019). Schaaf et al. (2014) proposed a system to store excess electricity produced from renewable sources such as solar and wind power plants and to use this electricity to provide hydrogen for the methanation with $\mathrm{CO}_{2}$. In another study, a retrofit unit was integrated into a gas turbine plant for methanation purposes. In that system, the $\mathrm{CO}_{2}$ was extracted from flue gas of the gas turbine plant, and hydrogen was provided from water electrolysis to produce methane (Boubenia et al., 2017). Direct methanation of flue gas was proposed using renewable hydrogen production by Laquaniello et al.(2018). The integration of hydrogen 
in PtG networks was assessed to find out its effect on the natural gas pipelines infrastructure (Gondal, 2019). A study focused on efficiency enhancement of a Sabatier-based PtG system by pinch analysis method, which revealed the significant potential of this concept. By thermoeconomic and sensitivity analysis, the critical components of the plant were highlighted (Toro and Sciubba, 2018). A system to integrate biogas plant to a membrane-based PtG system was also proposed. Two different processes for methanation were compared to study their feasibility (Kirchbacher et al., 2018). Applications of PtG were studied by retrofit plants in building energy systems through three different configurations (De Santoli et al., 2017). The impact of curtailment of wind-based generation on PtG was performed and the results showed that the impact of the activity was positive (Gholizadeh et al., 2019). A hybrid technology using PtG-biomass was reported to be most suitable in process industries (Bailera et al., 2016). Several studies have shown substantial cost reduction for methanation process and electrolysis, and this trend should continue until 2050 (Thema et al., 2019). Thermo-economic analysis of Sabatier based PtG plant was achieved to enhance plant efficiency (Toro and Sciubba, 2018). Thermodynamic, economic and environmental analyses were performed and showed promising results considering that water electrolysis will experience investment cost reduction (Boubenia et al., 2017). In another research, a 100 MW PtG was proposed and analyzed from an economic point of view, in which the system used solid oxide cell to both produce hydrogen and to use it reversibly for electricity generation when power is lacking (Miao and Chan, 2019). In a study, a gas turbine, an air bottoming cycle and a steam reforming unit were integrated for electricity and hydrogen production (Ahmadi et al., 2020). They found that adding steam reforming unit to the integrated gas and air bottoming cycles could enhance the energy and exergy efficiencies, and this combination would be advantagous from economic and environmental aspects.

The previous studies conclude that the utilization of carbon dioxide in syngas production is highly required because of the lower impact during combustion. In the present study, an integrated new 
system configuration using electricity from steam cycle and wind power plant along with gas through oxy-fuel combustion unit to produce syngas has been investigated. Thermal performance analysis of the plant has been performed in this study. The entire plant is a complex system due to the number of components working simultaneously in parallel and in series combination. This new system with such configuration has never been proposed so far. In this novel configuration, in the burner, coal is burned with air to produce hot gas. Hot gas energy is recovered in the Rankine cycle and absorption chiller to produce electricity and cooling. Sulfur components are removed from the exhaust gas and $\mathrm{CO}_{2}$ is reacted with hydrogen in the methanation plant to produce syngas $\left(\mathrm{CH}_{4}\right)$. This syngas is pressurized with compressor and stored in the pressure vessel. The syngas produced at the outlet of the plant can be compressed and utilized for vehicles as a fuel. Energy and exergy analyses of individual components of the proposed plant have been proposed. The electrical power consumption of the system components matches the electricity produced by both the Rankine cycle and wind turbine. The novelties of this study are the proposal of an integrated new configuration of power to gas cycle with energy recovery of exhaust hot gas from the boiler. The reduction of a large portion of $\mathrm{CO}_{2}$ emissions via conversion to syngas by using wind energy is an important aspect, which is highly desirable to reduce environmental pollution in present situation. Sensitivity analysis of the main parameters of this system is performed to evaluate the impact of several decision variables on the system performance.

\section{Mathematical modeling}

\subsection{Process description}

The schematic diagram of the system is shown in Figure 1 . In this system, coal (point 1 ) is reacted with air (point 2) and oxygen produced in the electrolyzer (point 15) to produce hot flue gas (FG) (point 3). Hot flue gas supplies the energy needs (points 3 and 4) of the evaporator of the Rankine Cycle (RC) to produce electricity by superheat organic working fluid (points 5 and 6). It is passed through absorber of absorption chiller (points 4 and 9) to produce cooling. After removing sulfur compounds (point 10), the 
flue gas is reacted with hydrogen supplied by the electrolyzer (point 12$)$ to produce syngas $\left(\mathrm{CH}_{4}\right)$ point 13. Produced syngas (point 13) is pressurized in the compressor (point 14) and it is stored in the pressure vessel for various applications. The electricity needs of compressor and electrolyzer are supplied by the electrical production of the wind turbine and Rankine cycle (steam power plant).

Extra electrical power production can be used by the user. The fuel of this system is coal and the outputs are cooling produced by absorption chiller, electrical power produced by both Rankine cycle and wind turbine, and syngas product.

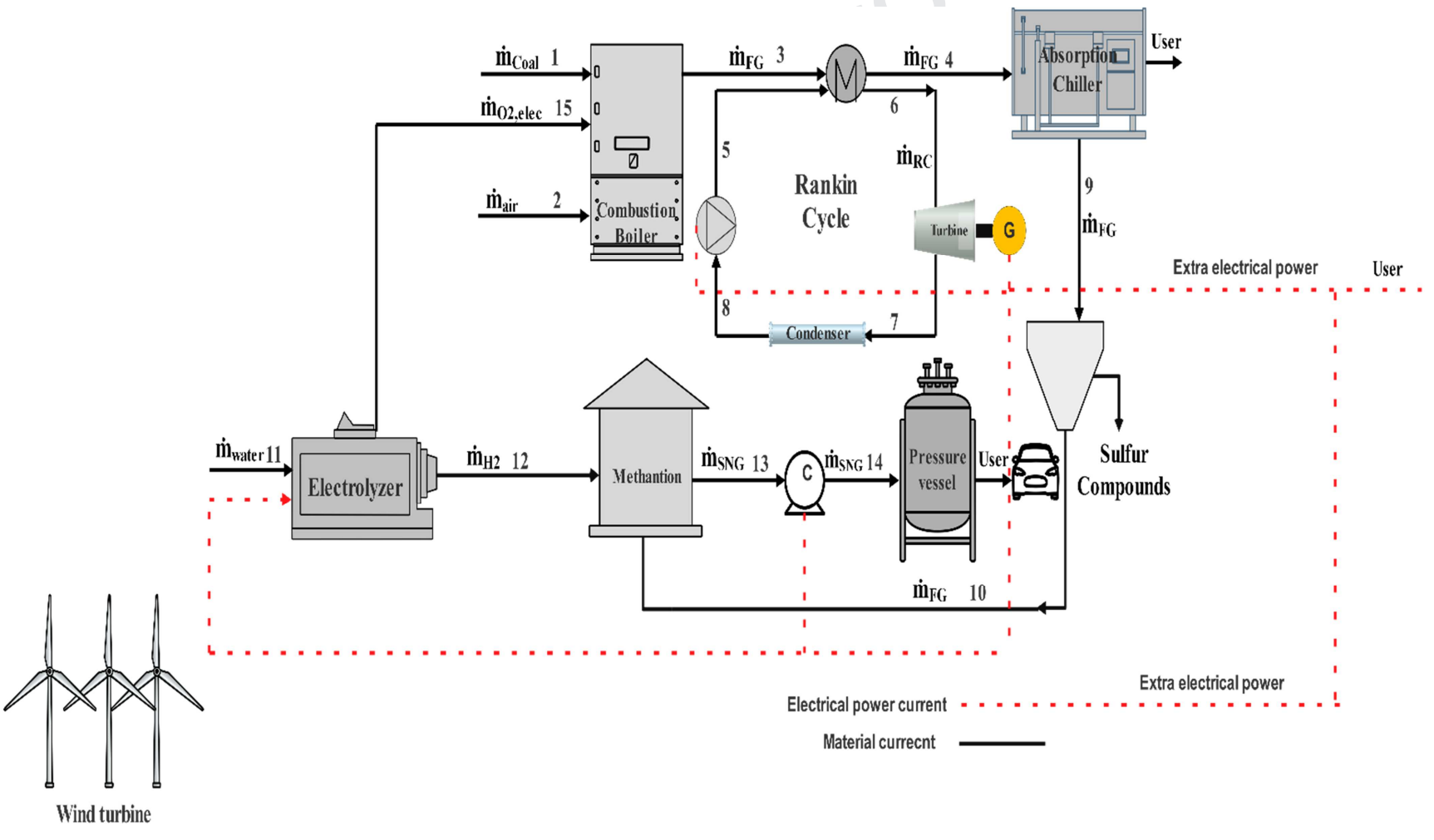

Figure1. Schematic diagram of the system

The considered assumptions in this model are as follows: 
$\mathrm{H}_{2} \mathrm{O}(\mathrm{I})+$ electrical energy $\rightarrow \mathrm{H}_{2}(\mathrm{~g})+\mathrm{O}_{2}(\mathrm{~g})$

3- Combustion boiler efficiency is 0.92 . power production by the wind turbine.

7- Pressure loss is assumed to be $2 \%$.

8- Flue gas loss is assumed to be $3 \%$.

\subsection{Mass and energy balances} are calculated by (Bailera et al., 2015):

$\dot{\mathrm{m}}_{\mathrm{O} 2}=\dot{\mathrm{m}}_{\mathrm{Coal}} \mathrm{r}_{\mathrm{a}}\left(2.667 \mathrm{x}_{\mathrm{C}}+\left(8 \mathrm{x}_{\mathrm{H}}-\mathrm{x}_{\mathrm{O}}\right)+\mathrm{x}_{\mathrm{S}}\right)$

$\dot{\mathrm{m}}_{\mathrm{air}}=4.32 \dot{\mathrm{m}}_{\text {Coal }} \mathrm{r}_{\mathrm{a}}\left(2.667 \mathrm{x}_{\mathrm{C}}+\left(8 \mathrm{x}_{\mathrm{H}}-\mathrm{x}_{\mathrm{O}}\right)+\mathrm{x}_{\mathrm{S}}\right)$ and sulfur, $r_{a}$ represents air fuel ratio.

4- The process in the pump and turbine is polytropic.

5- For the wind speed, the Weibull distribution density function is considered to calculate the

6- The polytropic efficiencies of the pump, turbine, and compressor are 0.85 .

9- Evaporator and condenser heat transfer efficiencies are assumed to be $90 \%$.

Based on the ultimate analysis of coal, the needs of oxygen and air mass flow rate for coal combustion

In equation 1 , the parameter $\mathrm{x}$ is the weight fraction, $\mathrm{C}, \mathrm{H}, \mathrm{O}$ and $\mathrm{S}$ denote carbon, hydrogen, oxygen

The alkaline electrolyzer is used to split water into hydrogen and oxygen. In general, the reaction presented by equation 3 takes place in the electrolyzer(Tijani et al., 2014; Ulleberg, 2003):

171 The operating voltage in each cell of the electrolyzer is calculated by (Tijani et al., 2014; Ulleberg, 2003):

$\mathrm{V}_{\text {cell }}=\mathrm{V}_{\text {rev }}+\mathrm{V}_{\mathrm{act}}+\mathrm{V}_{\mathrm{ohm}}$

172 In equation 4, subscripts rev, act and ohm denote reversible, activation and ohmic. The calculation

173 equations for $V_{\text {rev }} V_{\text {act }}$ and $V_{\text {ohm }}$ are presented in Table 1 (Tijani et al., 2014; Ulleberg, 2003). 


\begin{tabular}{|c|c|c|}
\hline No & Parameter & Equation \\
\hline 1 & $\mathrm{~V}_{\text {rev }}$ & $\frac{\Delta \mathrm{G}}{2 \mathrm{~F}}$ \\
\hline 2 & $\mathrm{~V}_{\text {act }}$ & $\mathrm{S} \log \left(\frac{\left(\mathrm{t}_{1}+\frac{\mathrm{t}_{2}}{\mathrm{~T}_{\text {elec }}}+\frac{\mathrm{t}_{3}}{\mathrm{~T}_{\text {elec }}}\right.}{\mathrm{A}} \mathrm{I}+1\right)$ \\
\hline 3 & & $\frac{\left(\mathrm{r}_{1}+\mathrm{r}_{2}\right) \mathrm{T}_{\text {elec }}}{\mathrm{A}}$ \\
\hline
\end{tabular}

177

178

179

180

181

182

$$
\eta_{F}=\frac{\left(\frac{I}{A}\right)^{2}}{f_{1}+\left(\frac{I}{A}\right)^{2}} f_{2}
$$

In equation $5, f_{1}$ and $f_{2}$ are the parameters related to electrolyzer and Faraday efficiencies.

Hydrogen production mass flow rate in alkaline electrolyzer is calculated by (Tijani et al., 2014; Ulleberg,

185 2003):

$$
\dot{\mathrm{m}}_{\mathrm{H} 2}=\eta_{\mathrm{F}} \mathrm{N}_{\text {cell }} \frac{\mathrm{I}}{\mathrm{F}}
$$

In equation $6, \mathrm{~N}_{\text {cell }}$ is the number of cells. 
The power consumption in alkaline electrolyzer is calculated by (Tijani et al., 2014; Ulleberg, 2003):

$\dot{\mathrm{W}}_{\text {elec }}=\mathrm{N}_{\text {cell }} \mathrm{V}_{\text {cell }}$

In the methanation plant, the reaction presented by equation 8 takes place (Bailera et al., 2015):

$\mathrm{CO}_{2}+4 \mathrm{H}_{2} \leftrightarrow \mathrm{CH}_{4}+2 \mathrm{H}_{2} \mathrm{O}$

The purity of $\mathrm{CO} 2$ has a significant impact on methanation efficiency. The considered $\mathrm{CO} 2$ capture technology is chemical absorption using amines (mono-ethanolamine, MEA).

For the wind turbine, the average electrical generated power is obtained by (Powell, 1981):

$\dot{\mathrm{W}}_{\text {wind,ave }}=\dot{\mathrm{W}}_{\text {wind,er }}\left[\frac{\exp \left(-\left(\frac{\mathrm{u}_{\mathrm{c}}}{\mathrm{C}}\right)\right)^{\mathrm{K}}-\exp \left(-\left(\frac{\mathrm{u}_{\mathrm{r}}}{\mathrm{C}}\right)\right)^{\mathrm{K}}}{\left(\frac{\mathrm{u}_{\mathrm{r}}}{\mathrm{C}}\right)^{\mathrm{K}}-\left(\frac{\mathrm{u}_{\mathrm{c}}}{\mathrm{C}}\right)^{\mathrm{K}}}-\exp \left(-\left(\frac{\mathrm{u}_{\mathrm{f}}}{\mathrm{C}}\right)\right)^{\mathrm{K}}\right]$

In equation $9, \mathrm{P}_{\mathrm{er}}$ is the rated power, $\mathrm{u}_{\mathrm{c}}, \mathrm{u}_{\mathrm{r}}$ and $\mathrm{u}_{\mathrm{f}}$ are cut-in rated and furling speeds. $\mathrm{K}, \mathrm{C}$ are

$\mathrm{K}=\left(\frac{\sigma}{\overline{\mathrm{u}}}\right)^{-1.086}$

$$
\mathrm{C}=\frac{\overline{\mathrm{u}}}{\Gamma\left(1+\frac{1}{\mathrm{k}}\right)}
$$

In equation 11, $\overline{\mathrm{u}}$ denotes the average wind speed, $\Gamma$ is the Gamma function and $\sigma$ is the standard deviation.

The system component energy and mass balances, as well as energy efficiency equations, are shown in

$$
\mathrm{KK}=\left[\frac{\dot{\mathrm{W}}_{\text {elec }}+\dot{\mathrm{W}}_{\mathrm{c}}+\dot{\mathrm{W}}_{\mathrm{p}}-\dot{\mathrm{W}}_{\mathrm{T}}}{\dot{\mathrm{W}}_{\text {windturbine,ave }}}\right]+1
$$


The brackets ([]) mean integer function.

System energy efficiency can be calculated by:

energy efficiency $=\frac{\dot{\mathrm{m}}_{13} \mathrm{LHV}_{\mathrm{CH}_{4}}+\mathrm{KK} * \dot{\mathrm{W}}_{\text {windturbine,ave }}+\dot{\mathrm{Q}}_{\mathrm{abs}}+\dot{\mathrm{W}}_{\mathrm{T}}-\dot{\mathrm{W}}_{\mathrm{C}}-\dot{\mathrm{W}}_{\mathrm{P}}}{\dot{\mathrm{m}}_{1} \mathrm{LHV} \mathrm{V}_{\mathrm{CH} 4}+\mathrm{KK} \dot{W}_{\text {windturbine,er }}}$

\subsection{Exergy balance}

Exergy is defined as the amount of work obtainable when some matter is brought to thermodynamic equilibrium with its surroundings. The total exergy consists of four components including kinetic exergy, potential exergy, physical exergy and chemical exergy (Bejan, 2016).

ex is the total specific exergy, calculated as (Bejan, 2016):

$$
e x=\left(h-h_{0}\right)-T_{0}\left(s-s_{0}\right)+T_{0} \sum x_{i} R \operatorname{Lny}_{i}+\sum x_{i} e_{c h i}+\frac{V^{2}}{2}+g z
$$

In equation $14, \mathrm{~h}$ is the enthalpy, $\mathrm{s}$ is the specific entropy, $\mathrm{R}$ is the specific gas constant, $\mathrm{ex}_{\mathrm{chi}}$ is the component specific chemical exergy, $x i$ is the mass fraction, yi is the molar fraction. $V$ is the velocity; $g$ is the gravitational acceleration and $z$ is the height. The notation " 0 " is the reference state condition (1atm, 288K).

For each component of the system, equations of exergy destruction rate and exergy efficiency are shown in Table $\mathrm{S} 2$ in appendix section.

System exergy efficiency can be calculated as:

exergy efficiency $=\frac{\dot{\mathrm{m}}_{13} \mathrm{ex}_{\mathrm{ch}, \mathrm{Ch} 4}+\mathrm{KK} * \dot{\mathrm{W}}_{\text {windturbine,ave }}+\dot{\mathrm{Q}}_{\mathrm{abs}}\left(1-\frac{\mathrm{T}_{0}}{\mathrm{~T}_{\mathrm{abs}}}\right)+\dot{\mathrm{W}}_{\mathrm{T}}-\dot{\mathrm{W}}_{\mathrm{C}}-\dot{\mathrm{W}}_{\mathrm{P}}}{\dot{\mathrm{m}}_{1} \mathrm{ex}_{1}+\frac{8}{27} \rho \mathrm{A}_{2} \mathrm{U}^{3}}$

System exergy destruction is calculated by the summation of system component exergy destructions. 
The total investment cost represented as $C_{0}$ is obtained by the equation 16 (Bellos et al., 2019; Tzivanidis et al., 2016):

$$
\mathrm{C}_{0}=\mathrm{K}_{\text {Wind turbine }}+\mathrm{K}_{\text {Absorption chiller }}+\mathrm{K}_{\text {Methanation }}+\mathrm{K}_{\mathrm{Elec}}+\mathrm{K}_{\mathrm{RC}}+\mathrm{K}_{\text {Compressor }}
$$

In equation 19, $\mathrm{r}$ and $\mathrm{N}$ denote discount factor and project lifetime that are considered to be $3 \%$ and 25

$$
\mathrm{SPP}=\frac{\mathrm{C}_{0}}{\mathrm{CF}}
$$

The Payback Period (PP) equation is as follows (Bellos et al., 2019; Tzivanidis et al., 2016): 
$\mathrm{PP}=\frac{\ln \left(\frac{\mathrm{C}_{\mathrm{F}}}{\mathrm{CF}-\mathrm{r} \cdot \mathrm{C}_{0}}\right)}{\ln (1+\mathrm{r})}$

232

233

234

235

236

237

238

239

240

241

242 The type of wind turbine is Nordic wind turbine with $1000 \mathrm{~kW}$ rated power. Specification of this wind

243 turbine is shown in Table 3.

Each index is independent of another one, which makes them significant individually. The initial cost functions and values are presented in Table S3 in appendix section.

\section{Results and discussion}

For mathematical modeling, a computational program was written in MATLAB software. This program is divided into one main program and two functions for calculating the fluid properties and wind turbine power production.

\subsection{System specification}

The ultimate analysis of coal is shown in Table 2 (Verma et al., 2010).

Table 2. Ultimate analysis of coal (weight based)

\begin{tabular}{|c|c|c|c|c|c|c|}
\hline$x_{C}$ & $x_{H}$ & $x_{O}$ & $x_{N}$ & $x_{S}$ & $x_{M}$ & $x_{Z}$ \\
\hline 65.72 & 5.27 & 7.1 & 1.29 & 1.69 & 8.09 & 10.84 \\
\hline
\end{tabular}

Table 3. Nordic wind turbine specification

\begin{tabular}{|c|c|c|c|}
\hline No & Parameter & Unit & Value \\
\hline 1 & $\dot{\mathrm{W}}_{\text {windturbine,er }}$ & $\mathrm{kW}$ & 1000 \\
\hline 2 & $\mathrm{u}_{\mathrm{C}}$ & $\mathrm{m} / \mathrm{s}$ & 4 \\
\hline 3 & $\mathrm{u}_{\mathrm{r}}$ & $\mathrm{m} / \mathrm{s}$ & 16 \\
\hline
\end{tabular}




\begin{tabular}{|c|c|c|c|}
\hline 4 & $\mathrm{u}_{\mathrm{f}}$ & $\mathrm{m} / \mathrm{s}$ & 22 \\
\hline 5 & $\mathrm{~h}$ & $\mathrm{~m}$ & 70 \\
\hline 6 & $\mathrm{~A}$ & $\mathrm{~m}^{2}$ & 2732 \\
\hline
\end{tabular}

245

246 The system specification is shown in Table 4. The wind velocity value at a certain speed for Tehran is

247 shown in Table S4 in the appendix section (Atabi et al., 2014).

Table 4. System specification

\begin{tabular}{|c|c|c|c|}
\hline No & Parameter & Unit & Value \\
\hline 1 & $\dot{\mathrm{m}}_{1}$ & $\mathrm{~kg} / \mathrm{s}$ & 0.04 \\
\hline 2 & $\mathrm{r}_{\mathrm{a}}$ & Molar basis & 2.34 \\
\hline 3 & LHV $_{\text {coal }}$ & $\mathrm{kJ} / \mathrm{kg}$ & 27213 \\
\hline 4 & $\mathrm{~T}_{\text {elec }}$ & $\mathrm{K}$ & 353.15 \\
\hline 5 & $\mathrm{~T}_{1}$ & $\mathrm{~K}$ & 288.15 \\
\hline 6 & $\mathrm{~T}_{2}$ & K & 288.15 \\
\hline 7 & $\mathrm{~T}_{4}$ & $\mathrm{~K}$ & 368.15 \\
\hline 8 & $\mathrm{~T}_{6}$ & $\mathrm{~K}$ & 1324.1 \\
\hline 8 & $\mathrm{~T}_{9}$ & $\mathrm{~K}$ & 338.15 \\
\hline 9 & $P_{5}$ & $\mathrm{kPa}$ & 8104 \\
\hline 10 & $\mathrm{P}_{6}$ & $\mathrm{kPa}$ & 8104 \\
\hline 11 & $\mathrm{P}_{7}$ & $\mathrm{kPa}$ & 40.5 \\
\hline 11 & $\mathrm{P}_{8}$ & $\mathrm{kPa}$ & 40.5 \\
\hline 11 & $\mathrm{~T}_{\text {pinch }}$ & $\mathrm{oC}$ & 30 \\
\hline
\end{tabular}




\begin{tabular}{|c|c|c|c|}
\hline 12 & $\eta_{\mathrm{CC}}$ & - & 0.92 \\
\hline 13 & $\eta_{\mathrm{C}}$ & - & 0.9 \\
\hline 14 & $\eta_{\mathrm{E}}$ & - & 0.9 \\
\hline 15 & $\eta_{\mathrm{T}}$ & - & 0.85 \\
\hline 16 & $\eta_{\mathrm{P}}$ & - & 0.85 \\
\hline 17 & $\eta_{\mathrm{Com}}$ & - & 0.85 \\
\hline 18 & $\mathrm{COP}_{19}$ & - & 0.87 \\
\hline 19 & $\mathrm{r}_{\mathrm{C}}$ & - & 8 \\
\hline
\end{tabular}

250 In Tables $3 \& 4, r_{a}$ is the air-fuel ratio (mass basis), $\mathrm{T}_{\text {pinch }}$ is the temperature difference between hot gas

251 and superheated steam, $\eta_{C C}$ represents the combustion chamber efficiency. $\eta_{T}, \eta_{P}$, and $\eta_{C}$ are turbine,

252 pump and compressor polytrophic efficiencies, COP defines the absorption chiller coefficient of

253 performance, $r_{c}$ is the compression factor of compressor, $\dot{W}_{\text {windturbine,er }}$ is the rated power of wind

254 turbine, $\mathrm{u}_{\mathrm{c}}, \mathrm{u}_{\mathrm{r}}$ and $\mathrm{u}_{\mathrm{f}}$ are cut-in, rated and furling speeds of the wind turbine, $\mathrm{h}$ is the tower height of

255 the wind turbine and $\mathrm{A}$ is the swept area wind turbine.

Figure 2 shows the monthly average wind turbine electrical power production during one year. 


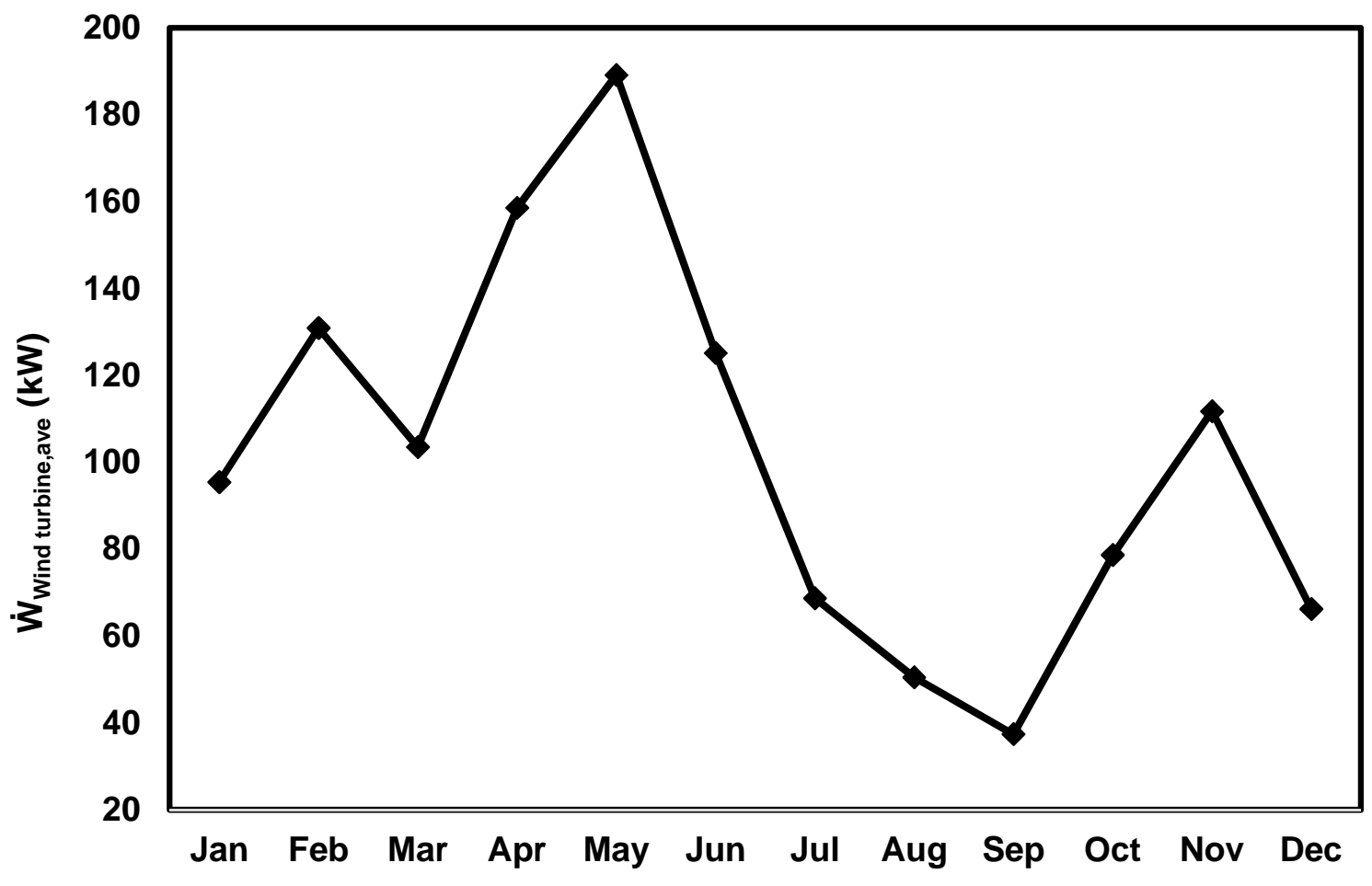

Figure 2. Monthly average wind turbine electrical power production during various months of a year

Table 5 shows the main system parameters calculated by the program.

Table 5. Results of the main parameters

\begin{tabular}{|c|l|c|c|}
\hline No. & Parameter & Unit & Value \\
\hline 1 & $\dot{\mathrm{W}}_{\text {elec }}$ & $\mathrm{kW}$ & 3214.2 \\
\hline 2 & $\dot{\mathrm{W}}_{\mathrm{P}}$ & $\mathrm{kW}$ & 1.65 \\
\hline 3 & $\dot{\mathrm{W}}_{\mathrm{T}}$ & $\mathrm{kW}$ & 243.4 \\
\hline 4 & $\dot{\mathrm{W}}_{\mathrm{C}}$ & $\mathrm{kW}$ & 16.2 \\
\hline 5 & $\dot{\mathrm{Q}}_{\mathrm{abs}}$ & $\mathrm{kW}$ & 22.6 \\
\hline
\end{tabular}

262 Based on equation 12, Table 3, and Figure 2, the required number of Nordic wind turbine units is shown

263 in Figure 3. According to Figure 3, the maximum number of wind turbines needed in September is equal 
to 80 . Since the conversion of all the carbon dioxide in flue gas is guaranteed by this system, the total number of 80 of $1 \mathrm{MW}$ Nordic wind turbine units is selected. For the other months of a year, the extra electrical power production can be delivered to electrical network.

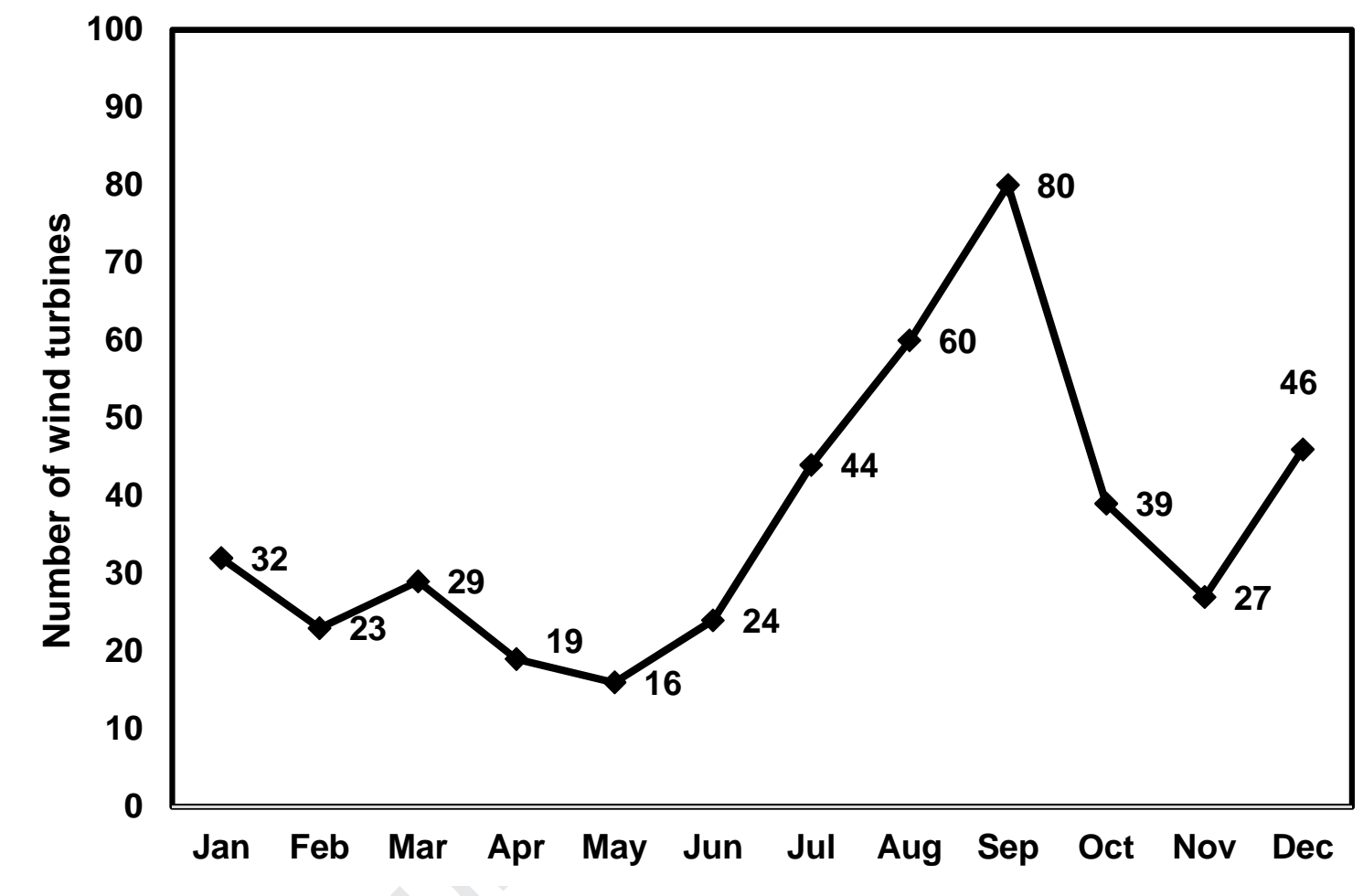

Figure 3. Required number of the Nordic wind turbine units

Table 6 shows the system comparison with and without syngas production during a year. Power for syngas production system is required in electrolyzer, compressor, and methanation plant. The consumption of electrical power to produce syngas is calculated to be equal to $25.6 \mathrm{MWh} / \mathrm{t}$.

Table 6. System comparison with and without syngas production

\begin{tabular}{|l|l|l|l|l|}
\hline \multirow{2}{*}{ No. } & \multicolumn{2}{|c|}{ Parameter } & \multirow{2}{*}{ Unit } & \multicolumn{2}{c|}{ Value } \\
\cline { 4 - 6 } & & & With syngas & Without syngas \\
\hline 1 & $\dot{\mathrm{m}}_{\mathrm{CO} 2}$ consumption & $\mathrm{t} / \mathrm{y}$ & 2776 & 0 \\
\hline 2 & $\dot{\mathrm{m}}_{\mathrm{H} 2}$ consumption & $\mathrm{t} / \mathrm{y}$ & 504.7 & 0 \\
\hline
\end{tabular}




\begin{tabular}{|l|l|l|l|l|}
\hline 3 & $\dot{\mathrm{m}}_{\text {Coal }}$ consumption & $\mathrm{t} / \mathrm{y}$ & 1152 & 1152 \\
\hline 4 & $\dot{\mathrm{m}}_{\text {syngas }}$ production & $\mathrm{t} / \mathrm{y}$ & 1009.4 & 0 \\
\hline 5 & $\dot{\mathrm{Q}}_{\text {abs }}$ cooling production & $\mathrm{MWh}$ & 180.5 & 180.5 \\
\hline 6 & electrical power production & $\mathrm{MWh}$ & 40920.4 & 66763.1 \\
\hline
\end{tabular}

273

\subsection{Validation of theoretical model}

Since a similar complex system has not been investigated yet, the validation of the whole system is impossible. Each of the main components is validated individually. The average power production of the Nordic wind turbine is compared with the manufacturer power curve shown in Ref. (Pierrot, 2019).

Regarding wind velocity information of Tehran (province of Iran) shown in Table S4, the annual average power produced by the Nordic model wind turbine is calculated to be $103.1 \mathrm{~kW}$ by equation 9 while it is $94.3 \mathrm{~kW}$ by power curve. The error is around $8 \%$, which can be due to the following reasons:

1) Equation 9 uses the statistical data of the wind turbine while the power curve is based on production power versus wind velocity.

2) The height of the tower is not determined in Ref. (Pierrot, 2019) and it is between 60 to 70 m, which has an effect on the power produced by the wind turbine.

3) For the power curve, the air density is considered to be $1.225 \mathrm{~kg} / \mathrm{m}^{3}$, while this value may differ for Tehran

For the alkaline electrolyzer, the theoretical model used in this study was validated before (Ulleberg, 2003). Figures 6 to 10 of this reference were compared to the simulation and experimental data. For example, in Figure 7 of this reference, the root means square (RMS) error for hydrogen production is $0.053 \mathrm{Nm}^{3} / \mathrm{hr}$ (in the range of 1 to $3 \mathrm{Nm}^{3} / \mathrm{hr}$ hydrogen production). 
For validation of the combustion chamber, the exhaust gas temperature was compared with Ref. (Anderson). In this reference, the process flow diagram (PFD) of one real coal-fired steam power plant is given. The hot exhaust gas temperature is determined to be $1259.2{ }^{0} \mathrm{C}$. By inserting the fuel and air ratios to computational code, this temperature is calculated to be $1324.6{ }^{0} \mathrm{C}$. The error is about $4.9 \%$. The main reasons for this error are as follows:

1) The coal composition is not specified and may be different

2) The distribution of the coal and air is different in the combustion chamber and the combustion is not uniform in real conditions

The plant energy efficiency in that reference is about $35.2 \%$, while it is about $30.1 \%$ in this study and the mean error is about $14 \%$ because of the lack of information about the main parameters in that reference. The steam turbine used in that reference has three stages (i.e., high, medium and low pressure steam), while the one stage steam turbine is considered in this study. The pure oxygen produced by the electrolyzer is injected to the burner, which brings another different feature between the two systems. The steam power plant energy efficiency is in a reasonable range. For further evaluation, the Ref (Suresh et al., 2012) is considered. The main configuration is modeled in the code. The plant energy efficiency is calculated at around $29.1 \%$, which is consistent with the plant energy efficiency shown in that ref (29.3\%).

\subsection{System energy and exergy analyses}

Figure 4 shows the annual average energy efficiency of various components of the system. The highest and lowest energy efficiencies are related to the compressor and steam power plant. 


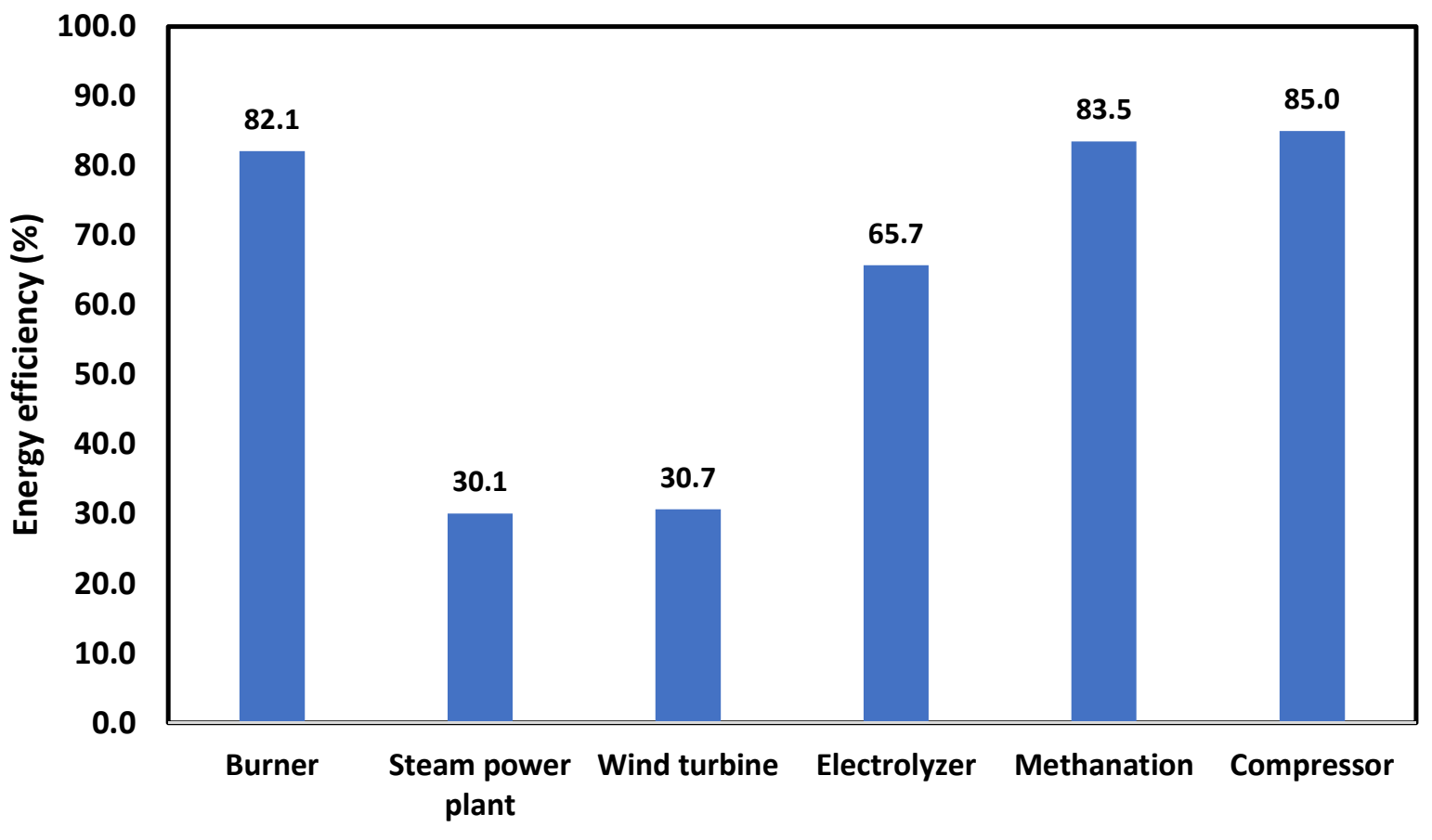

Figure 4. Annual average energy efficiencies of various system components.

Figure 5 shows the annual average exergy efficiency of various components of the system. Compared with Figure 4, although the highest exergy efficiency is still related to the compressor, the lowest exergy efficiency is here related to the wind turbine.

Exergy efficiency of the burner is lower than its energy efficiency. From the exergy viewpoint, this phenomenon is due to the fact that chemical reactions usually reduce exergy efficiency and increase the exergy destruction rate. This phenomenon is also true for the electrolyzer and the methanation plant. Wind turbine exergy efficiency is usually lower than wind turbine energy efficiency. The difference between energy and exergy efficiencies is because power rate of wind turbine is considered for thermal efficiency. For exergy efficiency, the exergy of wind velocity is considered (numerator of wind turbine exergy efficiency). 


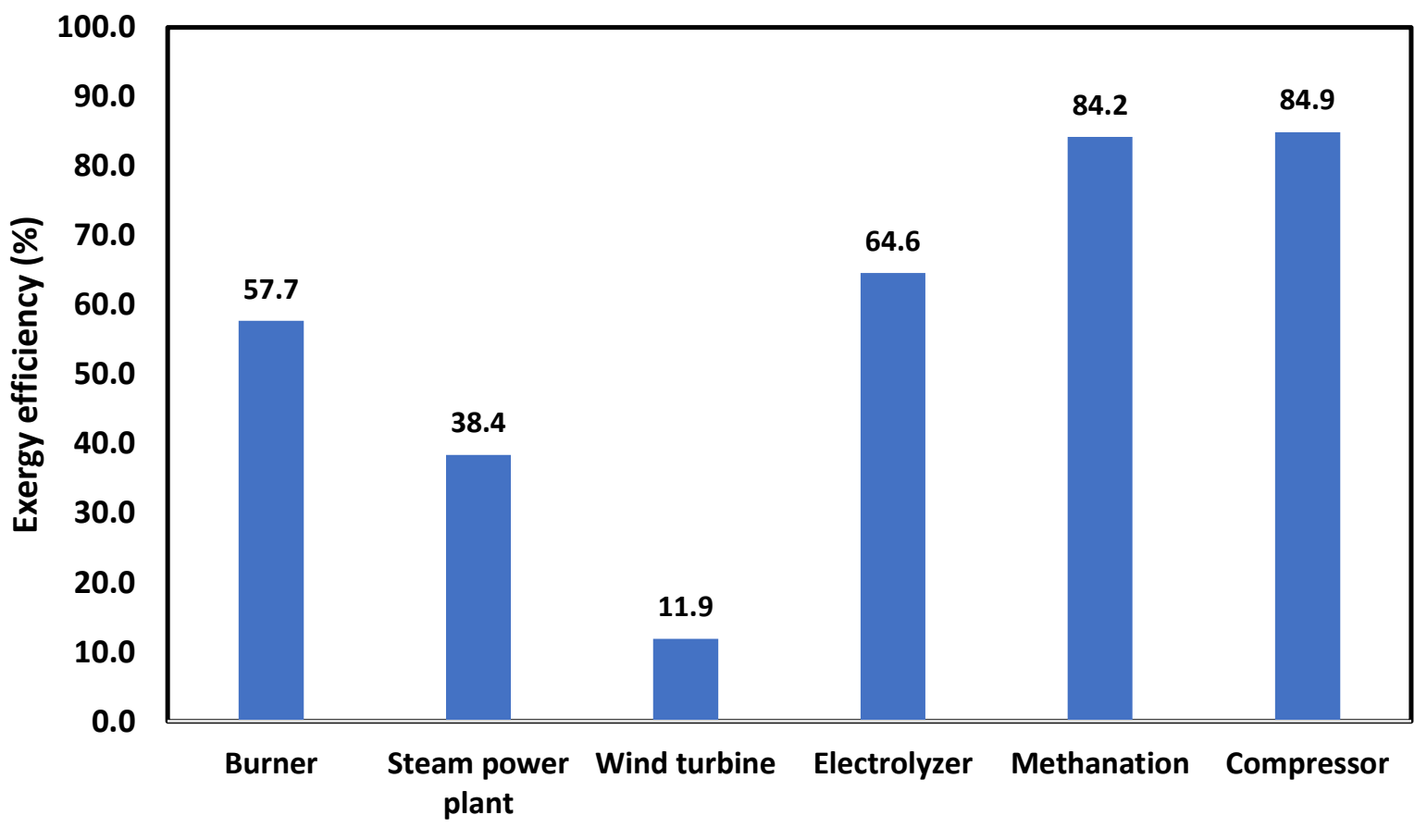

Figure 5. Annual exergy efficiency of various system components

325 Figure 6 represents the annual average exergy destruction rate for each component of the steam power 326 plant (Rankine cycle). The maximum exergy destruction rate is related to the evaporator because of the 327 heat absorbed from the hot flue gas (points 3 and 4). Heat transfer is generally one of the main sources 328 of exergy destruction. Power consumption of pumps is usually very low in the steam power plants; the 329 exergy destruction is also low as a result. In the condenser, since heat is dissipated to the environment, exergy destruction is very low. 


\section{0}

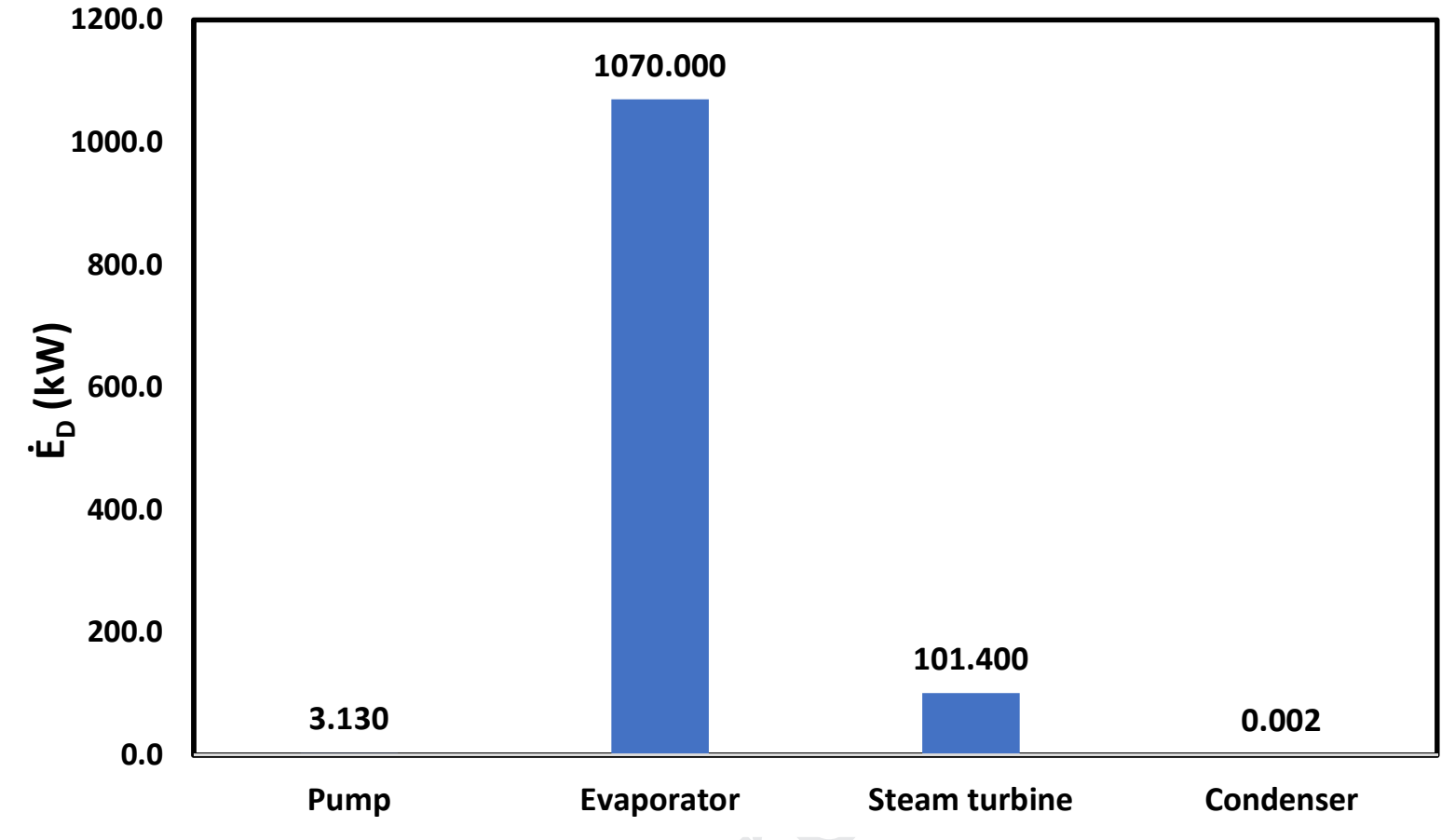

Figure 6. Annual average exergy destruction rate for various components of steam power plant

Figure 7 shows the annual average exergy destruction rate for various components of the system. The maximum exergy destruction rate is related to the steam power plant which is equal to $1174.5 \mathrm{~kW}$. Since the steam cycle includes four components (evaporator, pump, steam turbine, and condenser) and all of them have significant exergy destruction rates, their summation is considerable.

The exergy destruction rate in electrolyzer is also high (1086.4 kW) due to chemical reaction. Exergy destruction in methanation and burner are considerable due to the same reason of electrolyzer. of wind velocity exergy is wasted in the wind turbine. 


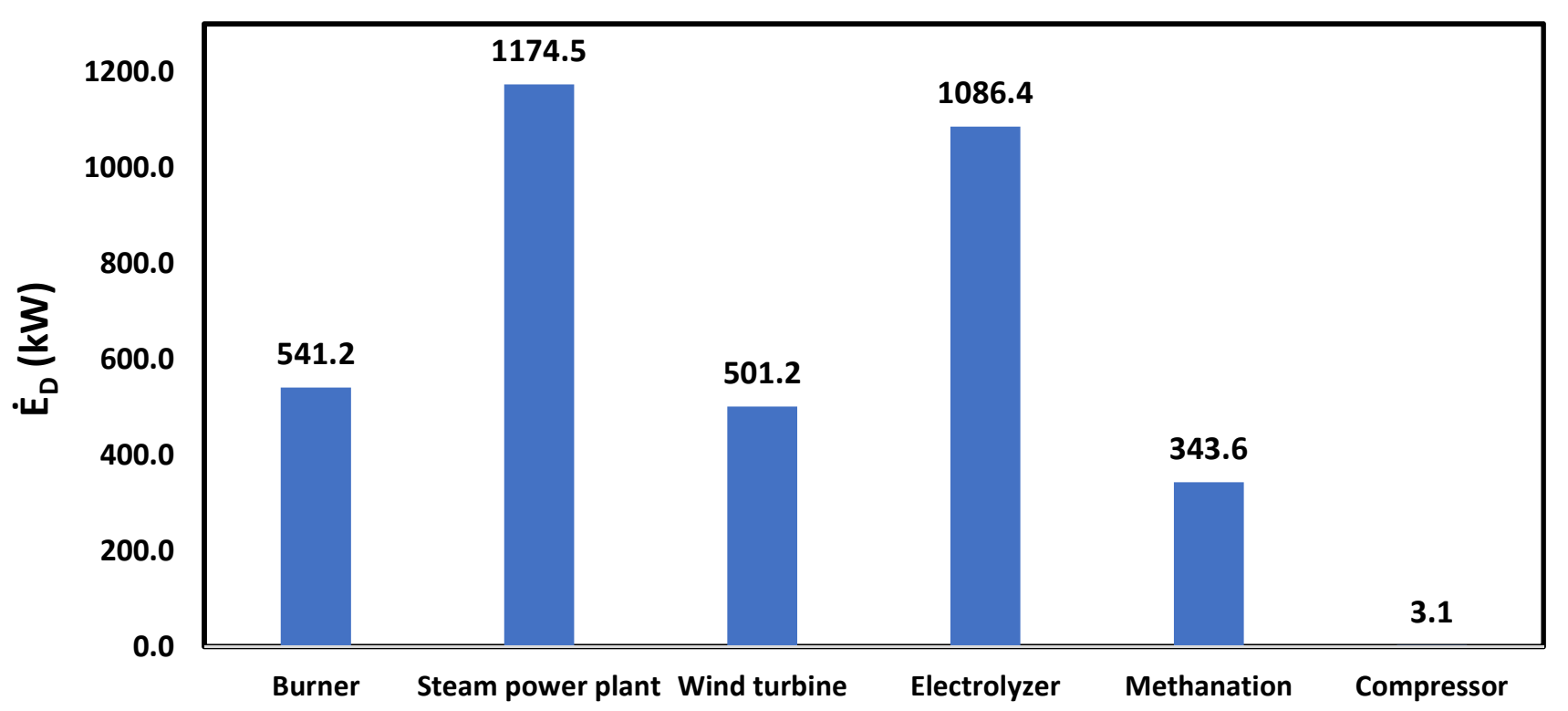

Figure 7. Annual average exergy destruction rate for various components of the system

Figure 8 illustrates the system energy and exergy efficiencies. Energy efficiency is slightly higher than exergy efficiency. In comparison to Figure 4, it is clear that system thermal efficiency is lower than all of the energy efficiencies of system components. In comparison to Figure 5, exergy efficiency of the system is higher than wind turbine exergy efficiency and lower than exergy efficiency of other system components. 


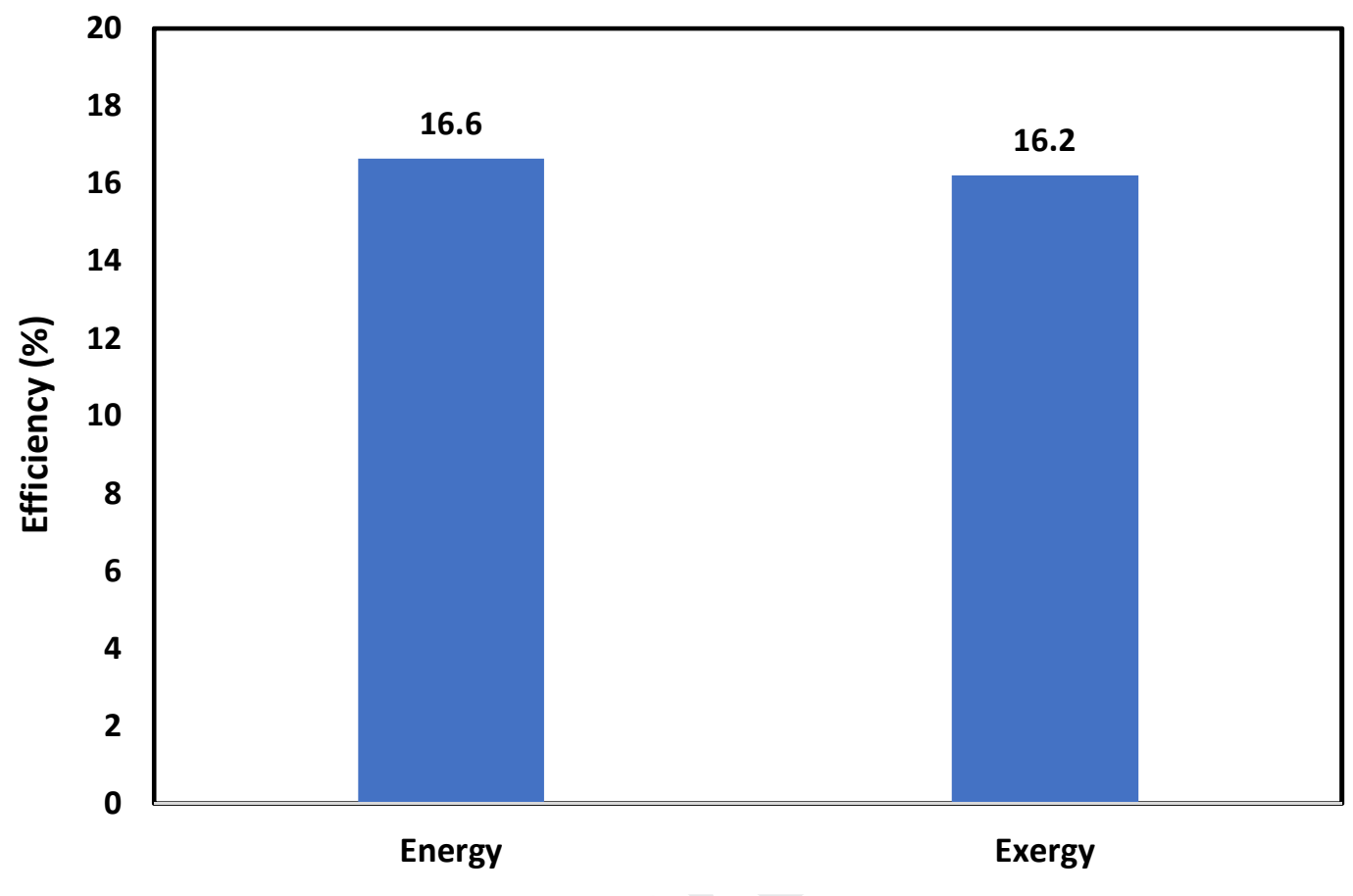
carbon tax are considered according to Table 7. 


\begin{tabular}{|c|c|c|c|c|}
\hline No. & Products and consumptions of system & Unit & Cost & References \\
\hline 1 & $\mathrm{k}_{\text {electrical }}$ & $\$ / k W h$ & 0.22 & $\begin{array}{l}\text { (Bellos et al., } \\
\text { 2019; Bellos et } \\
\text { al., 2016; Bellos } \\
\text { et al., 2017; } \\
\text { Kreuter and } \\
\text { Hofmann, 1998; } \\
\text { Nakomčić- } \\
\text { smaragdakis and } \\
\text { Dragutinović, } \\
\text { 2016; Tzivanidis } \\
\text { et al., 2016) }\end{array}$ \\
\hline 2 & $\mathrm{k}_{\text {cooling }}$ & $\$ / k W h$ & 0.074 & $\begin{array}{l}\text { (Bellos et al., } \\
\text { 2019; Bellos et } \\
\text { al., 2016; Bellos } \\
\text { et al., 2017; } \\
\text { Kreuter and } \\
\text { Hofmann, 1998; } \\
\text { Nakomčić- } \\
\text { smaragdakis and } \\
\text { Dragutinović, } \\
\text { 2016; Tzivanidis } \\
\text { et al., 2016) }\end{array}$ \\
\hline 3 & & $\$ / k W h$ & 0.12 & $\begin{array}{l}\text { (Bellos et al., } \\
\text { 2019; Bellos et } \\
\text { al., 2016; Bellos } \\
\text { et al., 2017; } \\
\text { Kreuter and } \\
\text { Hofmann, 1998; } \\
\text { Nakomčić- } \\
\text { smaragdakis and } \\
\text { Dragutinović, } \\
\text { 2016; Tzivanidis } \\
\text { et al., 2016) }\end{array}$ \\
\hline 4 & $\mathrm{k}_{\text {Coal }}$ & $\$ / \mathrm{t}$ & 66.58 & $\begin{array}{l}\text { (Guandalini et al., } \\
\text { 2017) }\end{array}$ \\
\hline 5 & $\mathrm{k}_{\mathrm{CO} 2}$ & $\$ / \mathrm{t}$ & 31.2 & $\begin{array}{l}\text { (Bellos et al., } \\
\text { 2019; Bellos et } \\
\text { al., 2016; Bellos } \\
\text { et al., 2017; } \\
\text { Kreuter and } \\
\text { Hofmann, 1998; } \\
\text { Nakomčić- } \\
\text { smaragdakis and } \\
\text { Dragutinović, } \\
\text { 2016; Tzivanidis } \\
\text { et al., 2016) }\end{array}$ \\
\hline
\end{tabular}


Table 8 shows the economic investigation results for the system with and without syngas production system. Syngas production system is including electrolyzer, methanation and compressor. The PP for the system with or without syngas production are calculated to be 11.2 and $7.4 \mathrm{y}$, and this difference could be justified by considering the components required for syngas production. The NVP for the system with or without syngas production is respectively 1.6 and 8.45 US\$. The IRR index for the system with or without syngas production is 10 and $15 \%$.

Table 8. Economic investigation results for the system with and without syngas production

\begin{tabular}{|l|l|c|c|c|}
\hline No. & Parameter & Unit & \multicolumn{2}{|c|}{ Values } \\
\cline { 4 - 5 } & & & $\begin{array}{c}\text { With } \\
\text { syngas }\end{array}$ & $\begin{array}{c}\text { Without } \\
\text { syngas }\end{array}$ \\
\hline 1 & SPP & Y & 9.4 & 6.6 \\
\hline 2 & PP & Y & 11.2 & 7.4 \\
\hline 3 & IRR & $\%$ & 0.1 & 0.15 \\
\hline 4 & NPV & US\$ & $1.6 \times 10^{8}$ & $8.45 \times 10^{7}$ \\
\hline 5 & CO & US\$ & $1.03 \times 10^{8}$ & $9.83 \times 10^{7}$ \\
\hline 6 & CF & US\$ & $1.09 \times 10^{7}$ & $1.49 \times 10^{7}$ \\
\hline
\end{tabular}

\subsection{System sensitivity analysis}

Figure 9 presents the relation between coal mass flow rate consumed by the system and syngas production. This relation is semi-linear. By changing the coal mass flow rate in the range of 0.01 to 0.1 $\mathrm{kg} / \mathrm{s}$, the syngas production mass flow rate is increased from 0.009 to $0.088 \mathrm{~kg} / \mathrm{s}$. This is because $\mathrm{CO}_{2}$ production increases linearly with mass flow rate of coal and syngas production shows the same trend as $\mathrm{CO}_{2}$ production.

Figure 10 shows the evolution of electrical consumption of alkaline electrolyzer as a function of coal mass flow rate burned in the burner. Similar to Figure 9, the relation is semi-linear. This is because 
hydrogen need increases linearly with $\mathrm{CO}_{2}$ production as well as coal consumption. The power consumption of electrolyzer exhibits a semi-linear relationship with hydrogen production in this system. portion of system electrical consumption.

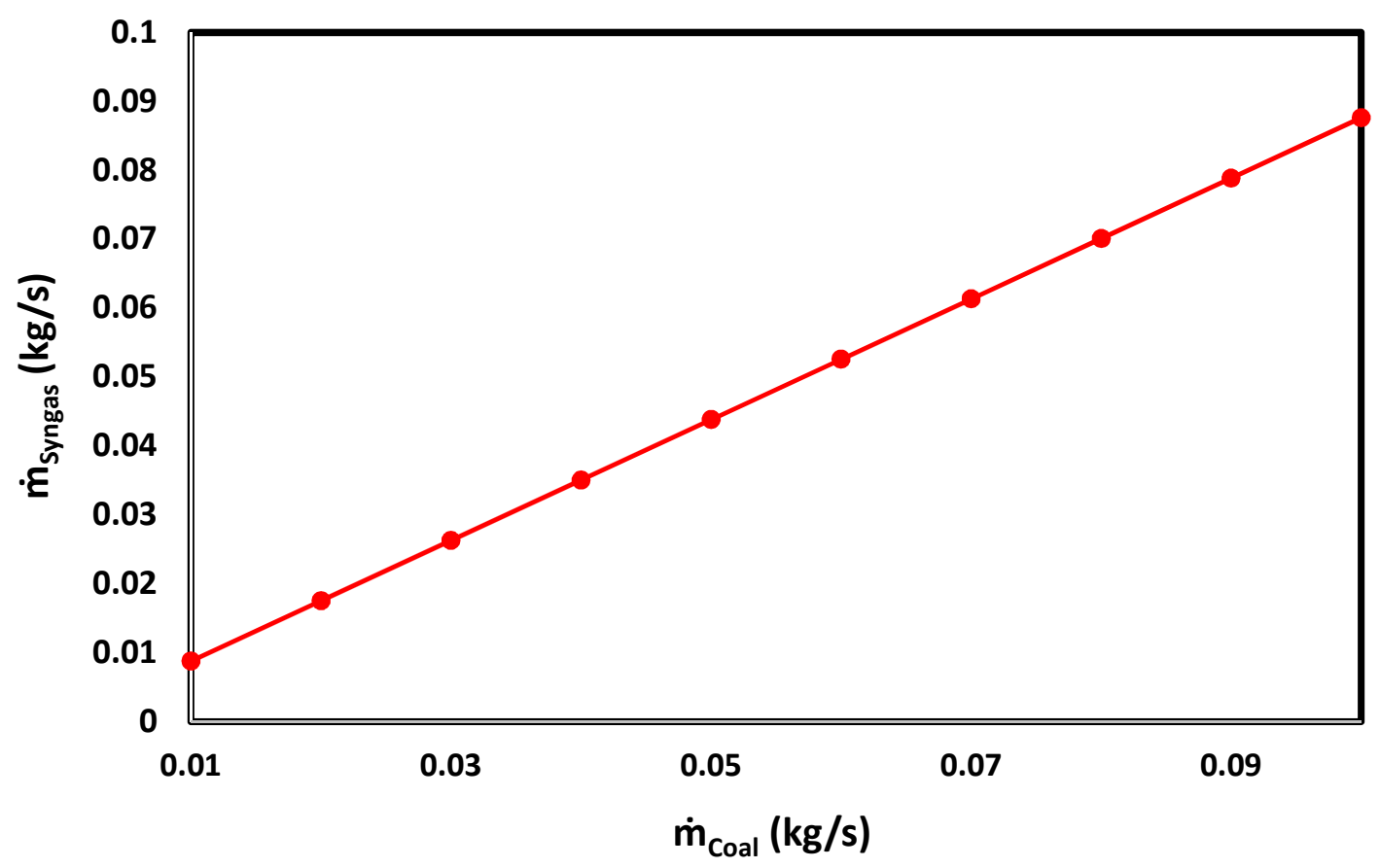

Figure 9. System syngas production versus coal mass flow rate consumption 


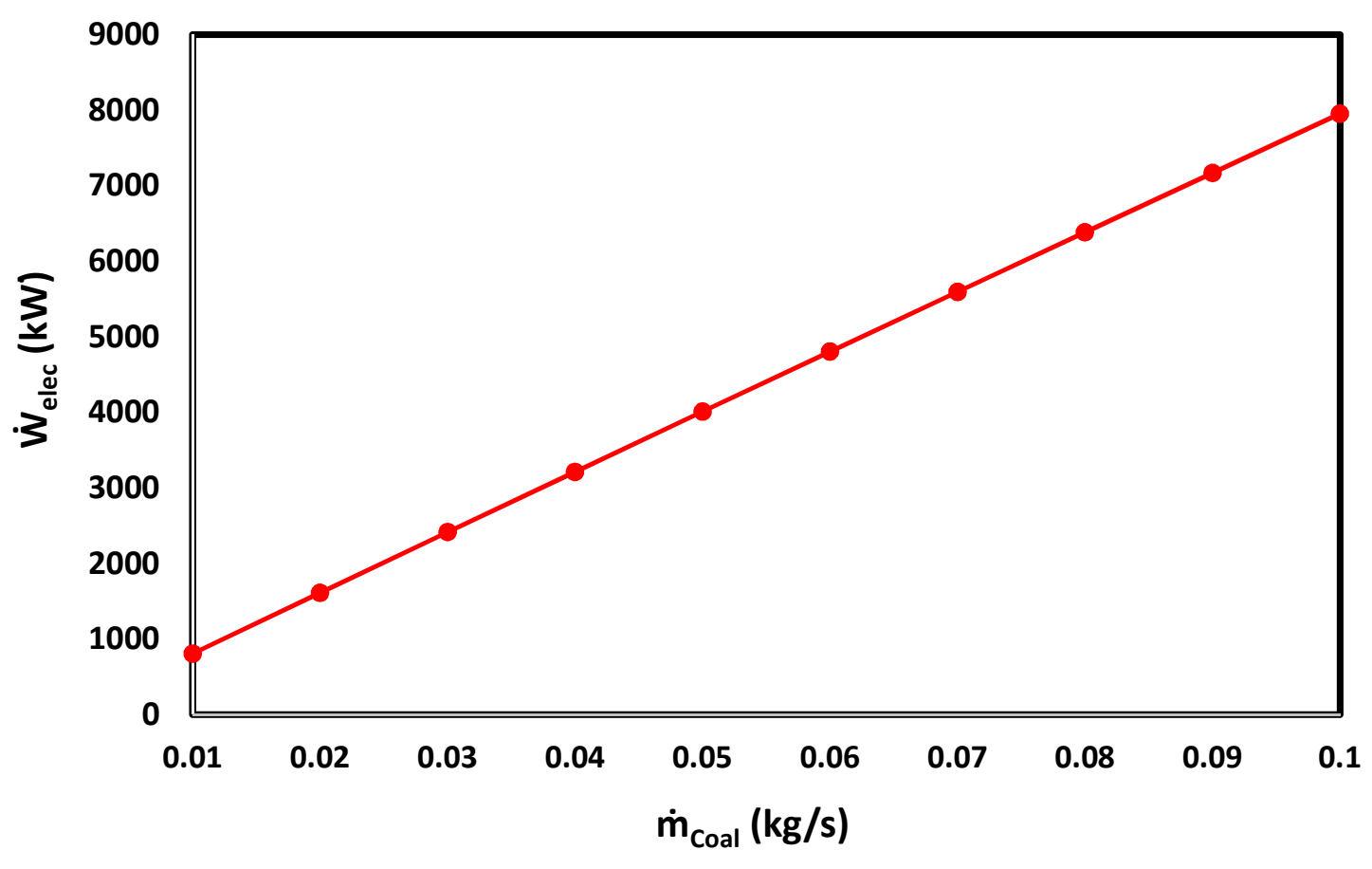

Figure 10. Evolution of electrical consumption of alkaline electrolyzer with coal mass flow rate

386 The effect of coal mass flow rate on variation of cooling produced in absorption chiller is reported in

387 Figure 11. By increasing the coal mass flow rate in the range of 0.01 to $0.1 \mathrm{~kg} / \mathrm{s}$, the cooling produced in

388 the absorption chiller is varied from 5.6 to $56.4 \mathrm{~kW}$. Increasing the coal mass flow rate generates

389 additional exhaust gas from the combustion chamber, thereby increasing the energy content of exhaust

390 gas, which in turn enhances (linear dependency) the cooling produced in the absorption chiller

391 (according to equation of absorption chiller shown in Table S1). 


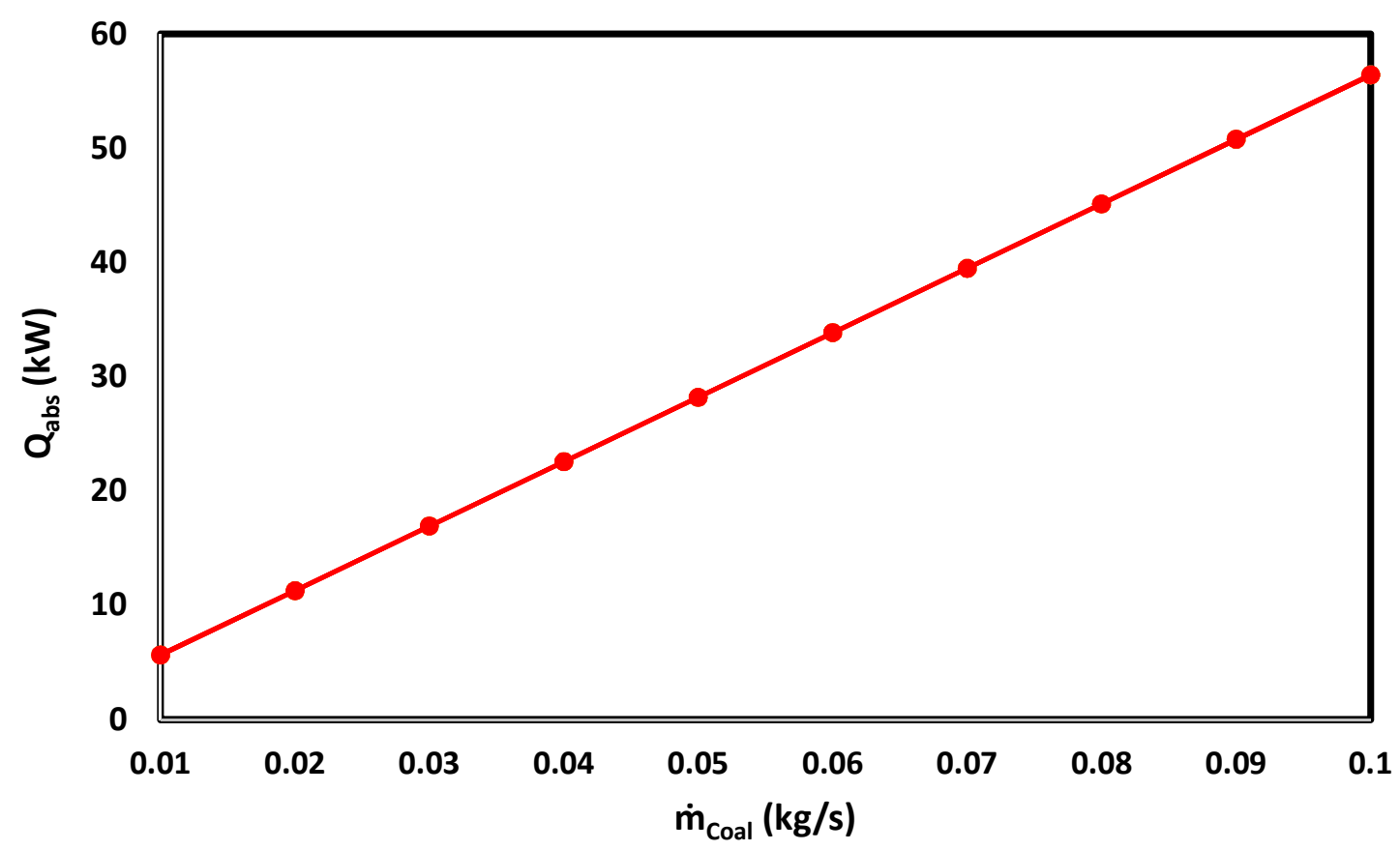

392

Figure 11. Variation of absorption chiller cooling production with coal mass flow rate

Figure 12 shows the system energy efficiency variation with the coal mass flow rate. The maximum system energy efficiency is reached for coal mass flow rate of $0.1 \mathrm{~kg} / \mathrm{s}$. The effect of coal mass flow rate on system energy efficiency is not considerable.

1) According to the equation 12 , by increasing the coal mass flow rate the number of wind turbines is increased to meet the electrical energy needs of electrolyzer. According to equation 13 , this increase has an effect on system energy efficiency (wind turbine power production and rated power.). The system energy efficiency is decreased as a result (negative effect) due to low potential of wind in Tehran.

2) The increase of the coal mass flow rate results in the increase of the electrical power production in steam power plant and cooling production in the absorption chiller as well as syngas 
production in methanation plant. According to equation 13, these phenomena lead to the increase of system energy efficiency (positive effect).

3) The increase of the coal mass flow rate causes the increase of electrolyzer power consumption (negative effect), since more oxygen should be produced to burn the coal in the combustion chamber.

410

From the whole contribution of these effects, the optimum coal mass flow rate is identified at $0.1 \mathrm{~kg} / \mathrm{s}$.

Figure 13 shows the system exergy efficiency variation with changes in the coal mass flow rate. Similar to Figure 12 , the trend of the curve is wavy due to the same reason as for the system energy efficiency behavior.

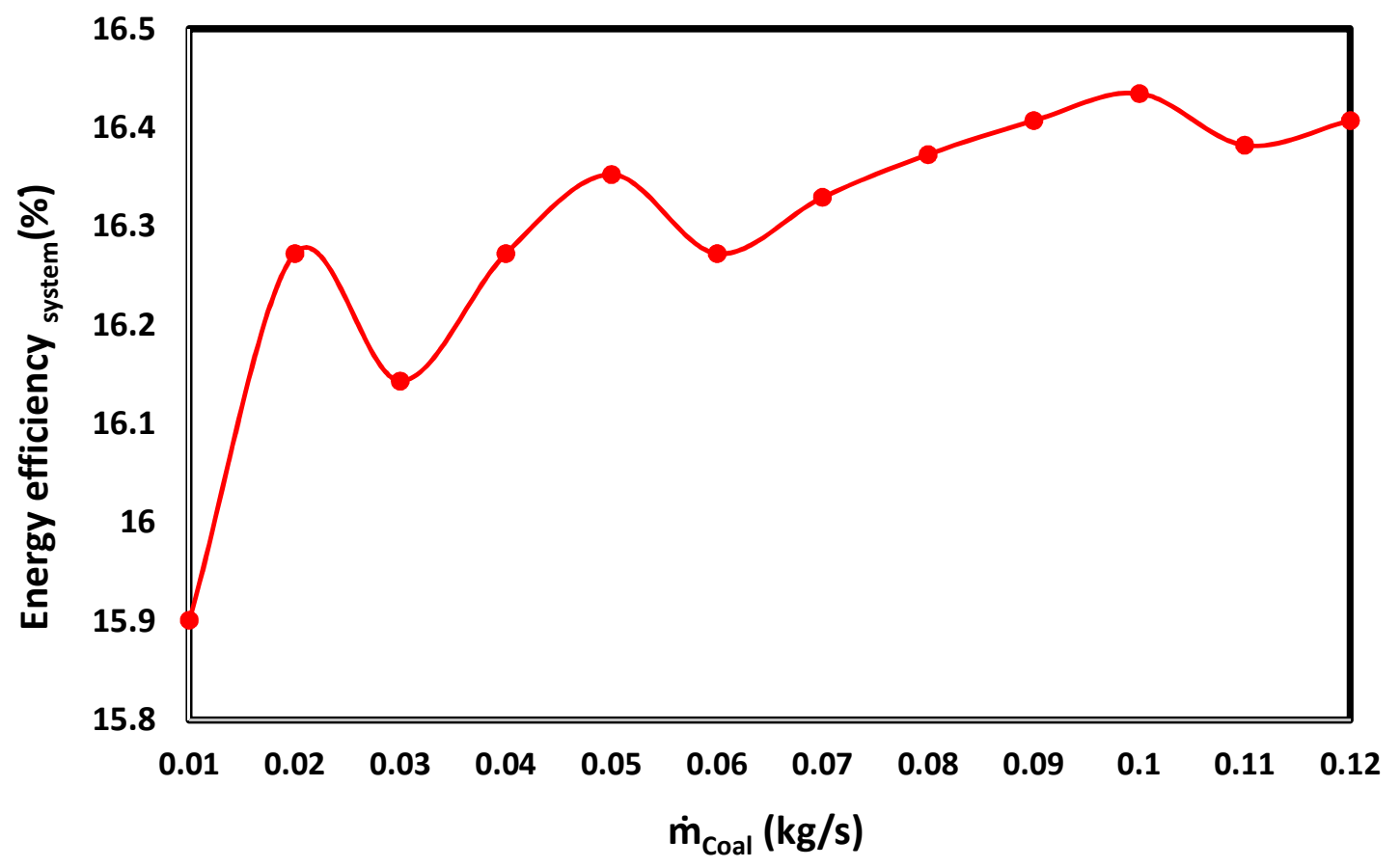

Figure 12. System energy efficiency variation with coal mass flow rate 


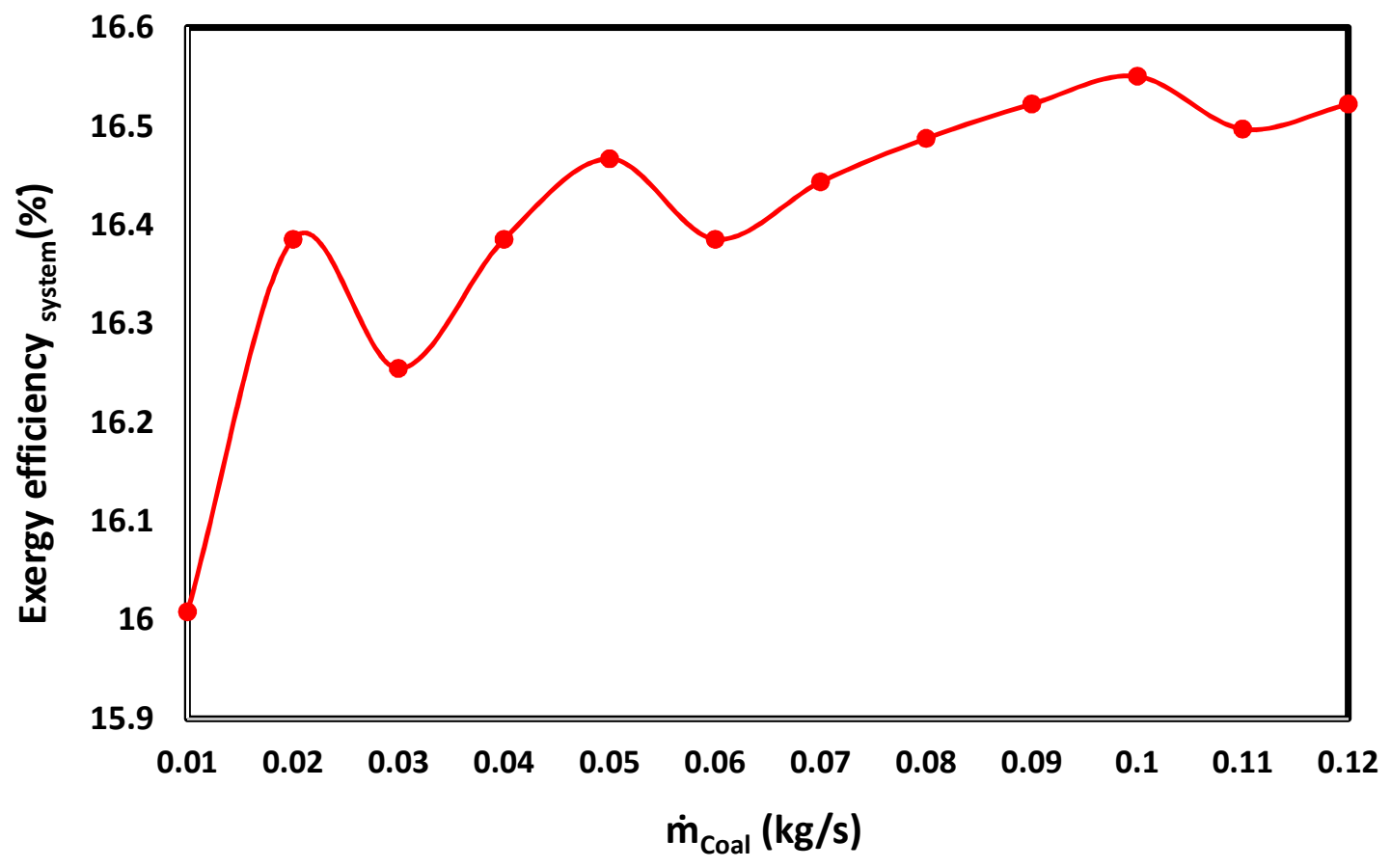

Figure 13. System exergy efficiency variation with coal mass flow rate.

The changes of system exergy destruction rate with variation of coal mass flow rate are presented in

Figure 14. In contrast to the system energy and exergy efficiency evolutions, the trend of this curve is linear. This phenomenon is due to the fact that increasing the number of wind turbines only increases the exergy destruction rate. In contrast, for the system energy and exergy efficiencies, increasing the number of wind turbines has an impact on both denominator and numerator of equations 13 and 15.

Figure 15 reveals the effect of air fuel ratio on burner energy and exergy efficiencies. By increasing air fuel ratio, both the energy and exergy efficiencies of the burner are reduced. By increasing air fuel ratio, the exhaust gas temperature is decreased. Regarding equations in Tables S1 \& S2, energy and exergy efficiencies are reduced. Increasing the exhaust mass flow rate also causes an increase of the number of wind turbines. This increase has a direct effect on the energy and exergy efficiencies of the system so that the trend of this curve is semi linear. 
431

432

433

434 and outlet exergy rates, the trend of this curve is semi linear.

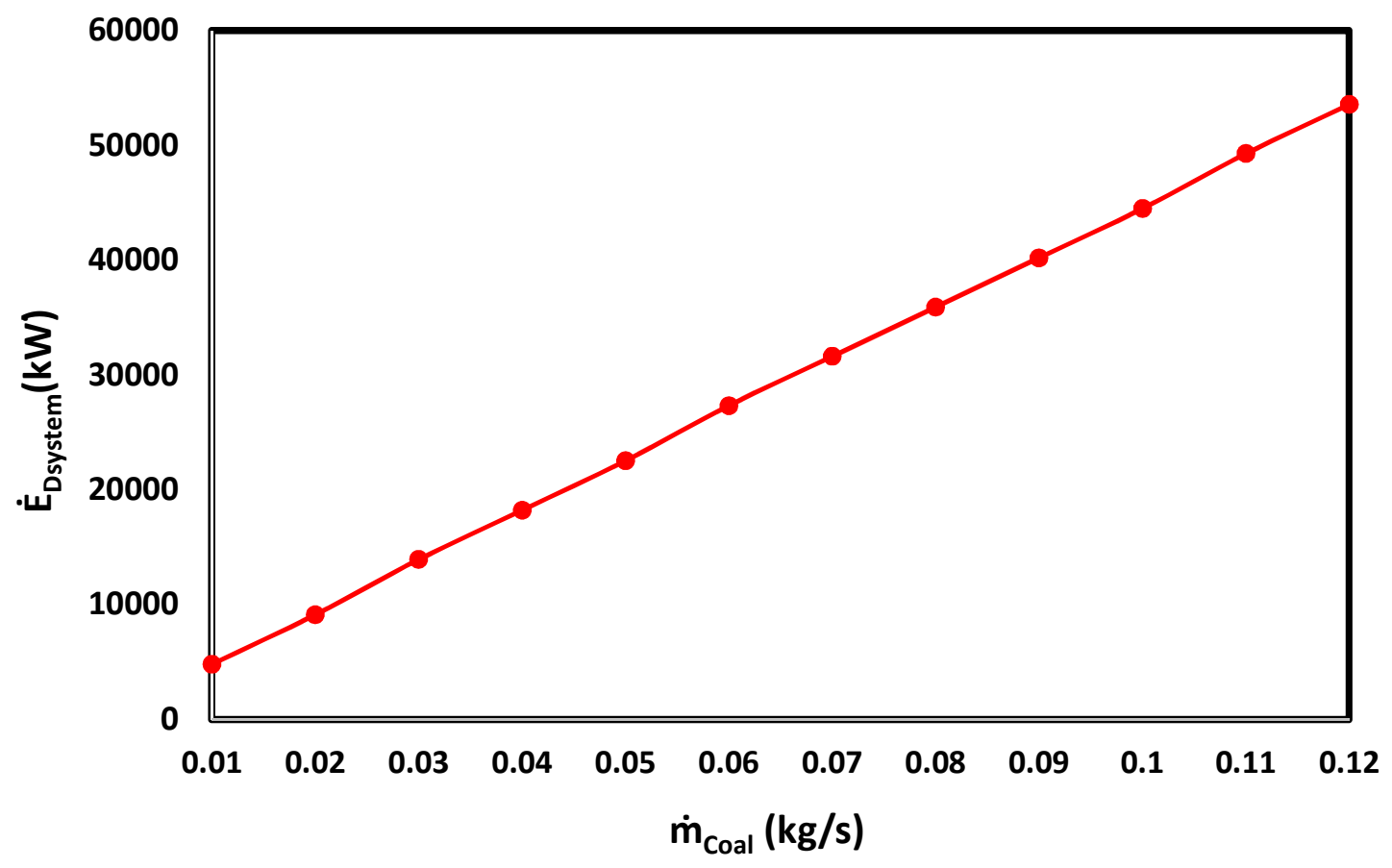

435 


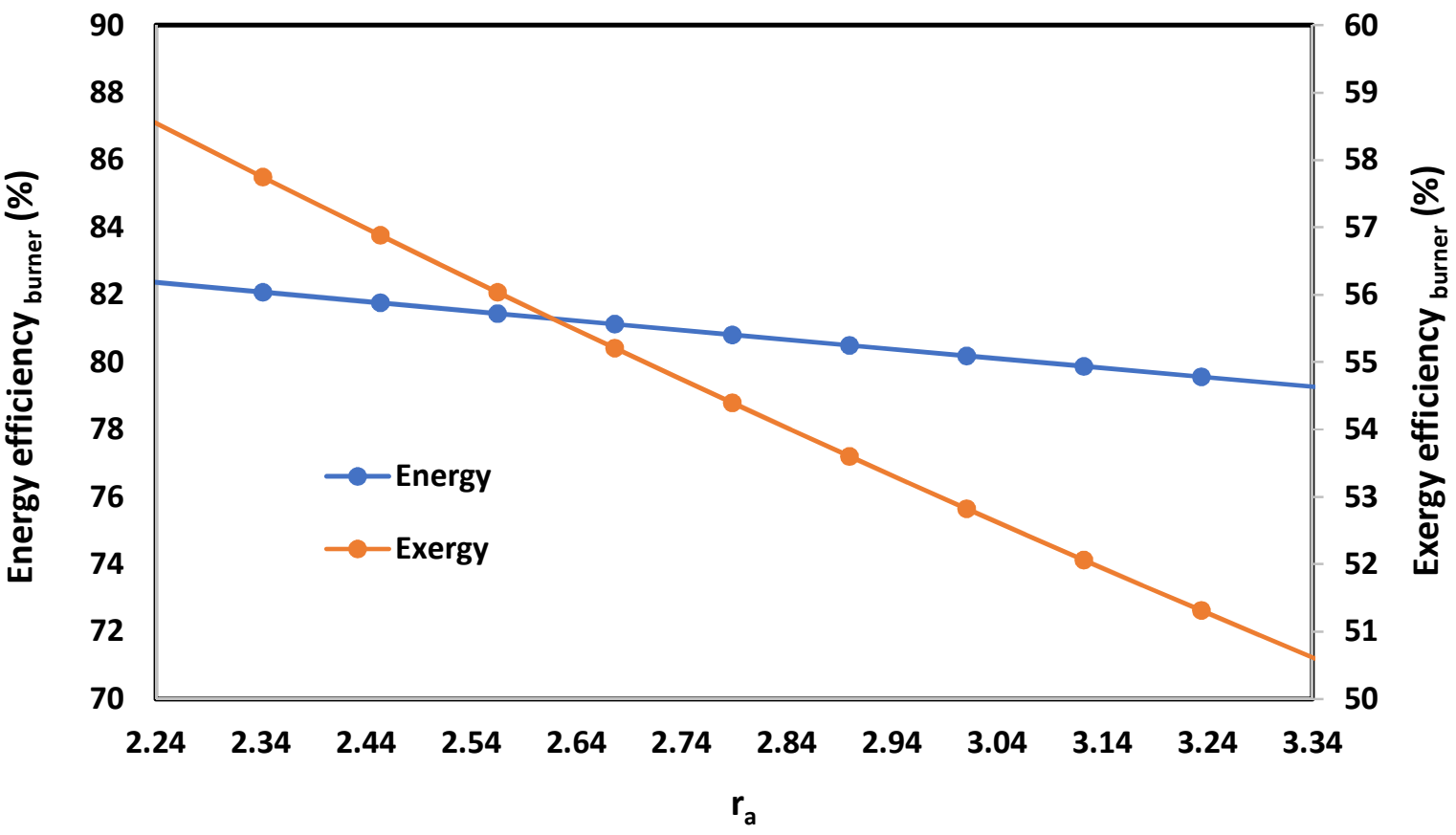

Figure 15. Effect of air fuel ratio on burner energy and exergy efficiencies

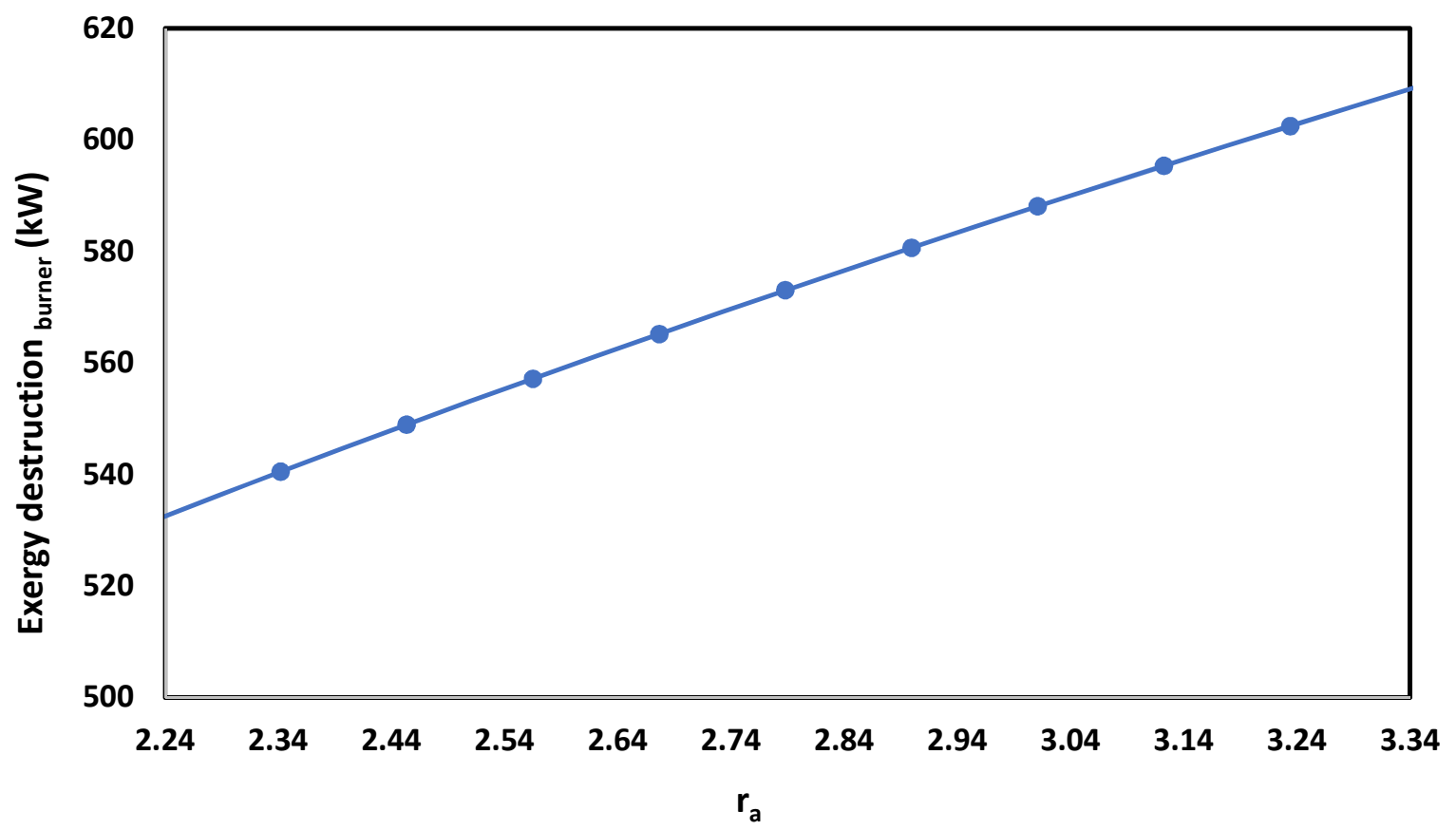

439 

energy and exergy efficiencies of the steam power plant.

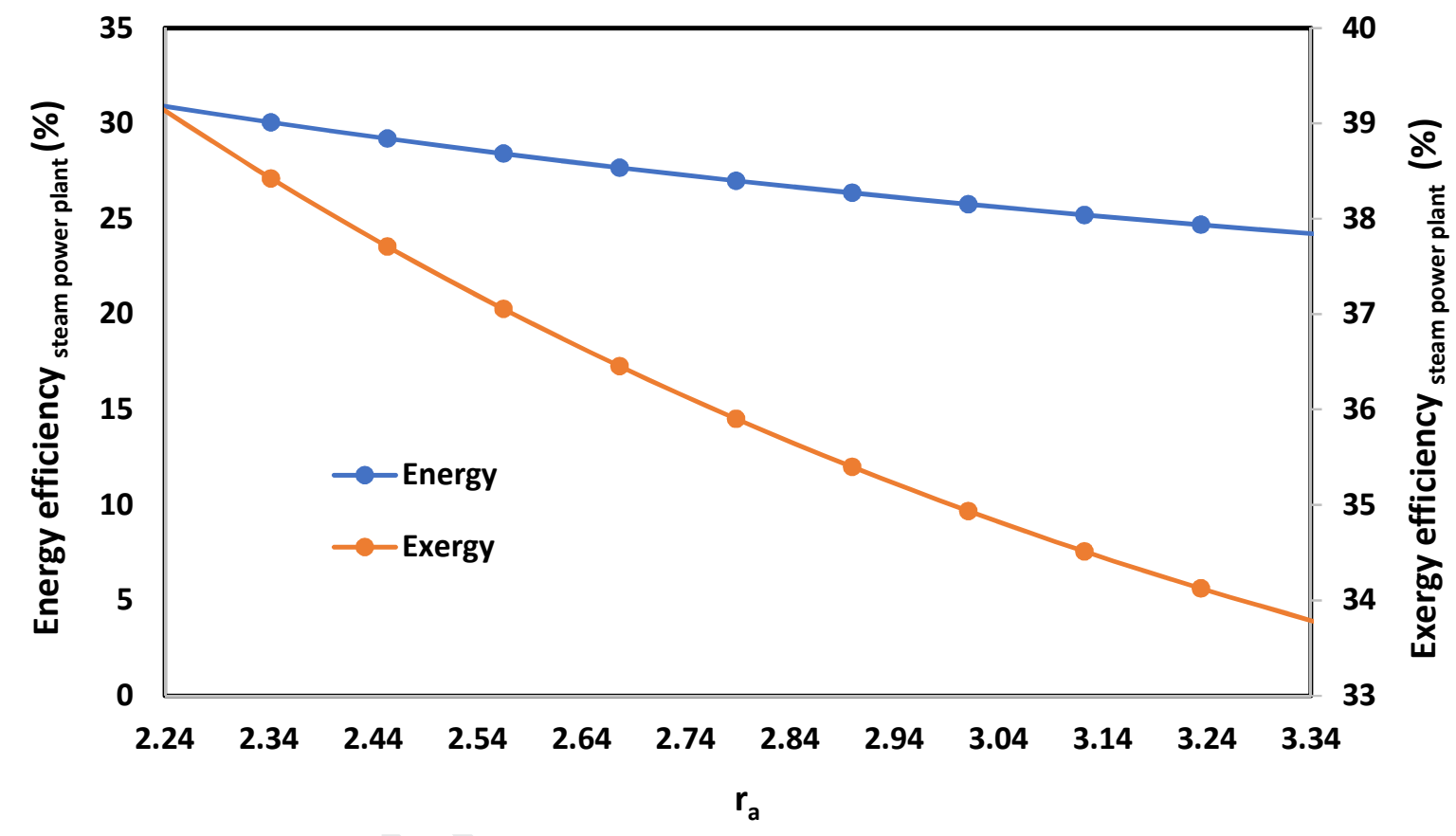

445

The impact of air fuel ratio on the steam power plant (Rankine cycle) energy and exergy efficiencies is shown in Figure 17. When increasing air fuel ratio, the temperature of hot exhaust gas is decreased, the heat source temperature of the steam power plant is decreased. This decrease causes a reduction in

Figure 17. Variation of steam power plant (Rankine cycle) energy and exergy efficiencies with air fuel ratio

The variation of the steam power plant exergy destruction rate with changes in air fuel ratio is illustrated in Figure 18. By increasing air fuel ratio, the exhaust gas temperature is decreased. The power produced in the steam power plant as well as exergy destruction rate is decreased too.

Figure 19 reports the effect of air fuel ratio on absorption chiller exergy destruction rate. By increasing air fuel ratio, two opposing effects can be observed:

1) Decreasing gas temperature in points 3 and 4 
2) Increasing mass flow rates in points 3 and 4

Although item 1 decreases the exergy destruction rate in the absorption chiller, item 2 increases this value. The item 2 overcomes item 1 so that the exergy destruction rate in absorption chiller is increased.

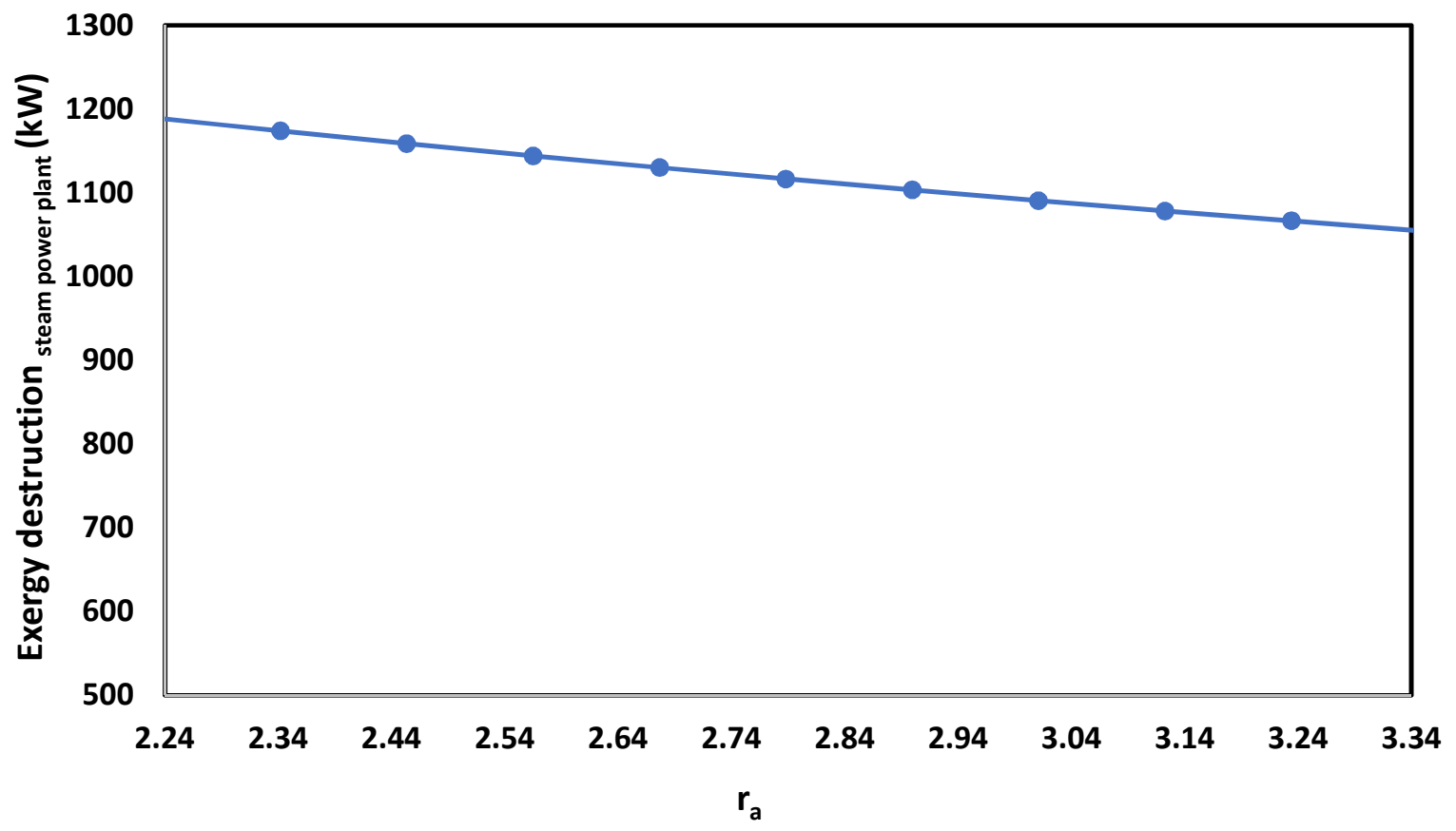




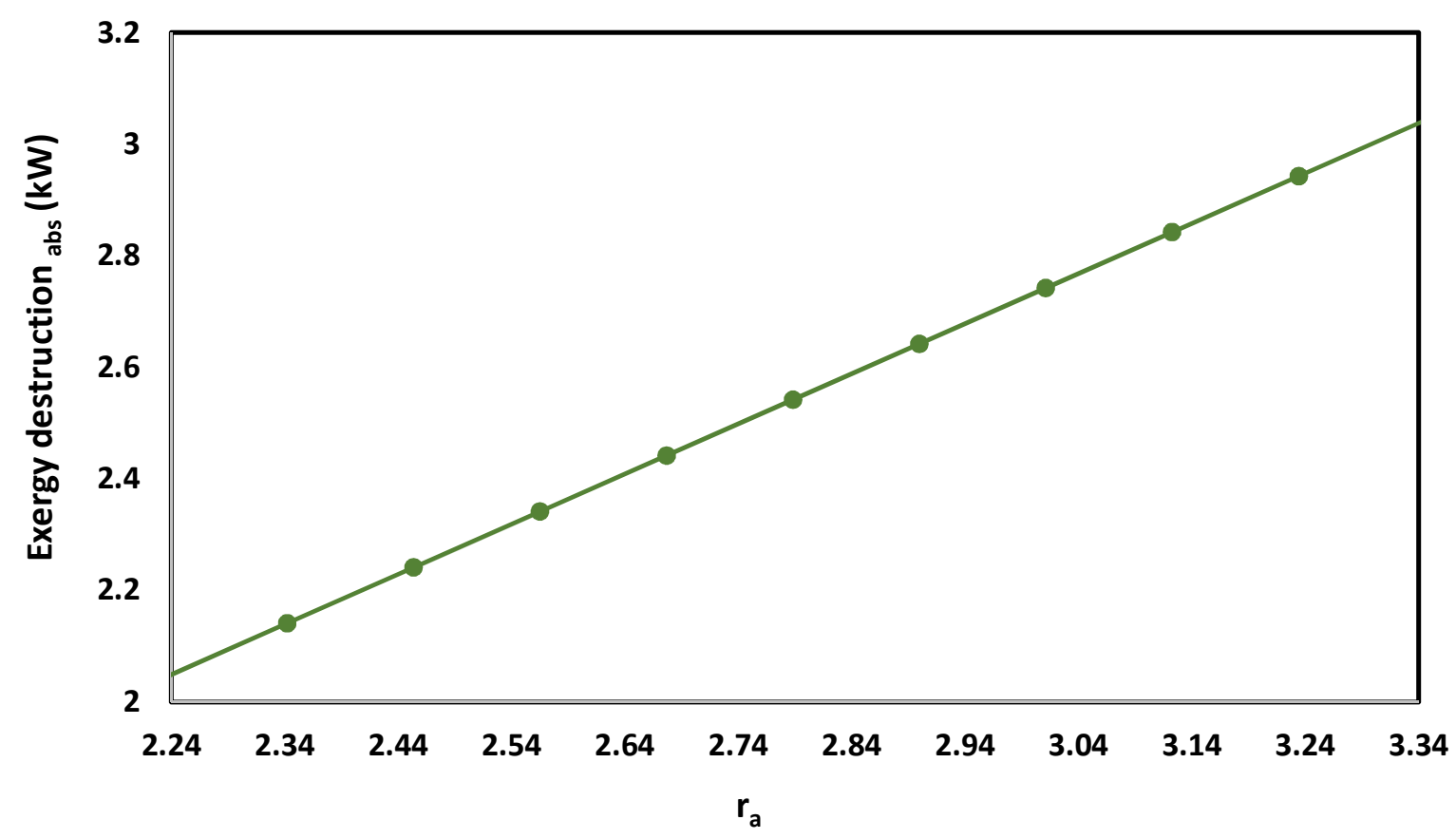

Figure 19. Variation of absorption chiller exergy destruction rate with air fuel ratio

461 Figure 20 presents the changes of systems energy and exergy efficiencies with variation of air fuel ratio.

462 By increasing air fuel ratio, the temperature of exhaust gas is decreased too. The power production in

463 Rankine cycle is decreased as a result. By increasing the power production in Rankine cycle, the system

464 energy and exergy efficiencies are decreased, but this reduction is not considerable.

465 


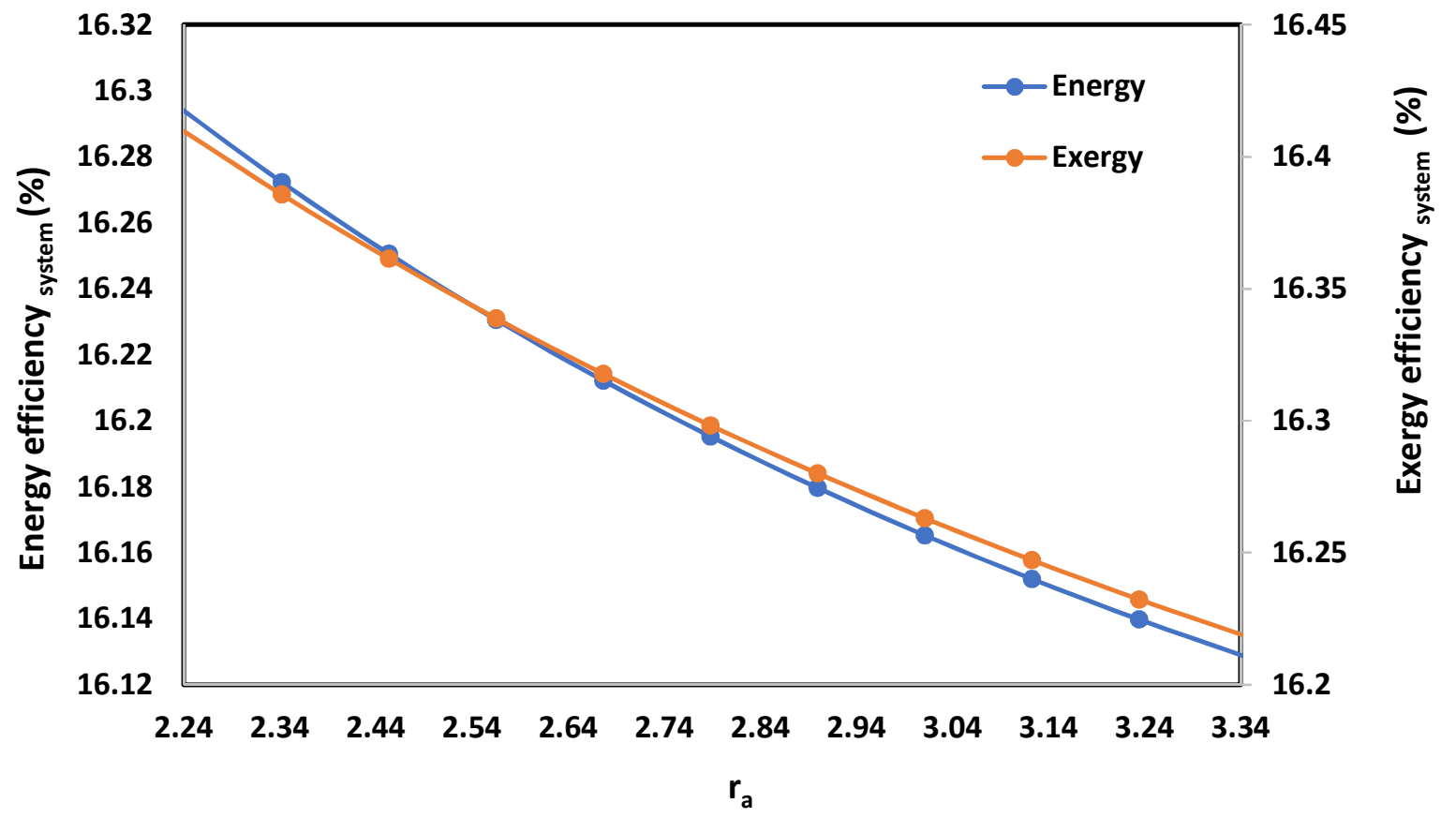

Figure 20. Variation of system energy and exergy efficiencies with air fuel ratio

470 In this study, a cogeneration system powered by the coal combustion chamber and wind turbines is 471 applied to produce electricity, cooling load and syngas from the $\mathrm{CO} 2$ emission of exhaust gas of the coal 472 combustion chamber. By this way, the heat of exhaust gas of the combustion chamber runs both a 473 Rankine cycle and an absorption chiller to generate electricity and cooling load. The exhaust gas of the combustion chamber finally flows through a sulfur extraction unit to separate sulfur from $\mathrm{CO} 2$. Then, the purified $\mathrm{CO} 2$ of exhaust gas reacts with hydrogen $(\mathrm{H} 2)$, which is produced from electrolysis of water in an electrolyzer unit. Meanwhile, the produced oxygen (O2) from the water electrolysis process is injected into the combustion chamber to increase the efficiency of the combustion. The energy, exergy and economic analyses of this cogeneration system have been performed.

479 The results of this study can be summarized as follows:

480 The proposed system is capable of producing 1009.4 metric ton of syngas annually and it can generate $481 \quad 180.5 \mathrm{MWh}$ of cooling load and 40920.4 MWh of electricity. This configuration produces syngas while avoiding the release of 2776 metric ton of $\mathrm{CO} 2$ annually. 
The energy efficiencies of main components consisting of methanation unit, steam power plant and wind turbine are about $85 \%, 30.1 \%$ and $30.7 \%$. In the meanwhile, the exergy efficiencies for these components are $84.2 \%, 38.4 \%$ and $11.9 \%$, respectively.

The results of this study show that the energy and exergy efficiencies of this hybrid system are $16.6 \%$ and $16.2 \%$, respectively.

The economic analysis reveals that the costs of electricity generation, cooling and syngas production are $0.22,0.074$, and $0.12 \$ / \mathrm{kWh}$, respectively.

The payback periods for this hybrid system with or without syngas production are 11.2 and 7.4 years, respectively.

Moreover, the internal rate of return (IRR) and net present value (NPV) for this cogeneration system with syngas production unit are $10 \%$ and 1.6 US\$, respectively whereas these economic parameters for the hybrid system without syngas production unit are $15 \%$ and 8.45 US\$.

For further study, the application of other renewable energy resources such as solar collector or geothermal energy instead of wind turbine is suggested for this cogeneration system. This configuration can be employed to capture more $\mathrm{CO} 2$ emissions from other hydrocarbon fuel combustion chambers as a future work of this study.

\section{Nomenclature}

\section{Subscript notations}

0

$1,2, \ldots, 15$

abs

act

Com

C

elec

E
Reference state condition (1atm, 288K)

Fifteen points in Figure 1

Absorption chiller

Activation

Compressor

Condenser

Electrolyzer

Evaporator 
FG

$\mathrm{H}$

ohm

0

P

rev

S

T

\section{Variables}

A

$\mathrm{A}_{2}$

Abs

C

$\mathrm{C}_{0}$

CF

COP

$\mathrm{c}_{\mathrm{p}}$

ex

$\mathrm{ex}_{\mathrm{chi}}$

$\dot{\mathrm{E}}_{\mathrm{D}}$

$f_{1}$ and $f_{2}$
Flue gas

Hydrogen

Ohmic

Oxygen

Pump

Reversible

Sulfur

Turbine

Area of electrode $\left(\mathrm{m}^{2}\right)$

Swept area of wind turbine $\left(\mathrm{m}^{2}\right)$

Absorption chiller

Parameter of wind turbine

Total investment cost (US\$)

Cost function (\$)

Coefficient of performance of absorption chiller

Specific heat at constant pressure $(\mathrm{kJ} / \mathrm{kgK})$

Total specific exergy $(\mathrm{kJ} / \mathrm{kg})$

Component specific chemical exergy $(\mathrm{kJ} / \mathrm{kg})$

Exergy destruction rate

Faraday efficiencies related to electrolyzer 
$\left(\mathrm{mA}^{2} / \mathrm{Cm}^{4}\right)$

$\mathrm{F}$

$\mathrm{h}$

I

IRR

K

K

KK

LHV

$\dot{\mathrm{m}}$

$\dot{\mathrm{m}}_{1}$

$\dot{\mathrm{m}}_{15}$

$\dot{\mathrm{m}}_{2}$

$\dot{\mathrm{m}}_{3}$

$\dot{\mathrm{m}}_{\mathrm{H} 2}$

$\mathrm{N}$

$\mathrm{N}_{\text {cell }}$

NPV

PP

02, elec

$P_{e r}$
Faraday`s constant (96495 C/mole)

Enthalpy (kJ/kg)

Current $(A)$

Internal Rate of Return

Parameter of wind turbine

Ratio (constant pressure divided to constant

volume specific heat)

Number of wind turbines

Lower heating value $(\mathrm{kJ} / \mathrm{kg})$

Mass flow rate $(\mathrm{kg} / \mathrm{s})$

$\dot{\mathrm{m}}_{\text {coal }}$

$\dot{\mathrm{m}}_{\mathrm{O} 2 \text {,elec }}$

$\dot{\mathrm{m}}_{\mathrm{air}}$

$\dot{\mathrm{m}}_{\mathrm{FG}}$

Hydrogen production mass flow rate in alkaline

electrolyzer

Project lifetime equal to 25 years (y)

Number of cells

Net Present Value (US\$)

Payback period (y)

Oxygen produced in the electrolyzer

Rated power of wind turbine (kW) 
$\dot{Q}$

$r_{1}$ and $r_{2}$

$r_{\mathrm{a}}$

$r_{c}$

R

$\mathrm{RC}$

$\mathrm{R}_{\mathrm{i}}$

r

$\mathrm{s}$

SPP

$t_{1}, t_{2}$ and $t_{3}$

$\mathrm{T}$

$\mathrm{T}_{1}$

$\mathrm{T}_{15}$

$\mathrm{T}_{2}$

$\mathrm{T}_{3}$

u

$\overline{\mathrm{u}}$

$u_{c}$

$u_{r}$

$u_{f}$

V

$\mathrm{V}_{\text {cell }}$
Heat transfer rate $(\mathrm{kW})$

Ohmic resistance parameters $\left(\Omega \mathrm{m}^{2}\right)$

Air fuel ratio

Compressor pressure ratio

specific gas constant ( $\mathrm{kJ} / \mathrm{kgK})$

Rankine cycle

Specific gas constant ( $\mathrm{kJ} / \mathrm{kgK})$

Discount factor equal to $3 \%$

Specific entropy (kJ/kgK)

Simple Payback Period (y)

electrode overvoltage coefficients $\left(\mathrm{m}^{2} / \mathrm{A}\right)$

Temperature (K)

$\mathrm{T}_{\text {coal }}(\mathrm{K})$

$\mathrm{T}_{\mathrm{O} 2 \text {,elec }}(\mathrm{K})$

$\mathrm{T}_{\text {air }}(\mathrm{K})$

$\mathrm{T}_{\mathrm{FG}}(\mathrm{K})$

Wind velocity $(\mathrm{m} / \mathrm{s})$

Average wind speed (m/s)

Cut-in speed (m/s)

Rated speed (m/s)

Furling speed (m/s)

Operating voltage (V)

Voltage of cells (V) 
$\dot{\mathrm{W}}$

$\dot{\mathrm{W}}_{\mathrm{c}}$

$\dot{W}_{\text {elec }}$

$\dot{\mathrm{W}}_{\text {wind,ave }}$

X

$\mathrm{x}_{1}$

$\mathrm{x}_{15}$

$\mathrm{x}_{2}$

$\mathrm{x}_{3}$

$\sigma$

$\rho$

$\eta_{\mathrm{C}}$

$\eta_{\mathrm{E}}$

$\eta_{\mathrm{CB}}$

$\eta_{\mathrm{Com}}$

$\eta_{F}$

$\eta_{P}$

$\eta_{\mathrm{T}}$

$\Delta \mathrm{G}$

$\Gamma$

500
Power transfer rate (kW)

Consumption power in the compressor (kW)

Consumption power in alkaline electrolyzer (kW)

Average electrical power generated by wind (kW)

turbine

Weight fraction

$\mathrm{x}_{\text {coal }}$

$\mathrm{x}_{\mathrm{O} \text {,elec }}$

$\mathrm{x}_{\text {air }}$

$\mathrm{X}_{\mathrm{FG}}$

Standard deviation

Air density $\left(\mathrm{kg} / \mathrm{m}^{3}\right)$

Condenser heat transfer efficiency

Evaporator heat transfer efficiency

Combustion loss efficiency

Polytrophic compressor efficiency

Current efficiency of alkaline electrolyzer

Pump polythrophic efficiency

Turbine polythrophic efficiency

Gibbs energy (equal to $237.2 \mathrm{~kJ} / \mathrm{mol}$ )

Gamma function 
Ahmadi, A., Jamali, D., Ehyaei, M.,Assad, M. E. H., 2020. Energy, Exergy, Economic and Exergoenvironmental analyses of gas and air bottoming cycles for production of electricity and hydrogen with gas reformer. Journal of Cleaner Production. 120915.

Anderson, B., 2015. Coal Fired Boiler-Principle 2. Seminar on Coal Fired Boiler, Malaysia.

Atabi, F., Ehyaei, M. A.,Ahmadi, M. H. (2014). Calculation of $\mathrm{CH} 4$ and $\mathrm{CO} 2$ emission rate in Kahrizak landfill site with LandGEM mathematical model. Paper presented at the The 4th world sustainability forum.

Bailera, M., Lisbona, P.,Romeo, L. M., 2015. Power to gas-oxyfuel boiler hybrid systems. International Journal of Hydrogen Energy. 40(32), 10168-75.

Bailera, M., Lisbona, P., Romeo, L. M.,Espatolero, S., 2016. Power to Gas-biomass oxycombustion hybrid system: Energy integration and potential applications. Applied energy. 167, 221-29.

Bejan, A., 2016. Advanced engineering thermodynamics. John Wiley \& Sons

Bellocchi, S., De Falco, M., Gambini, M., Manno, M., Stilo, T.,Vellini, M., 2019. Opportunities for powerto-Gas and Power-to-liquid in CO2-reduced energy scenarios: The Italian case. Energy.

Bellos, E., Pavlovic, S., Stefanovic, V., Tzivanidis, C.,Nakomcic-Smaradgakis, B. B., 2019. Parametric analysis and yearly performance of a trigeneration system driven by solar-dish collectors. International Journal of Energy Research. 43(4), 1534-46.

Bellos, E., Tzivanidis, C.,Antonopoulos, K. A., 2016. Exergetic, energetic and financial evaluation of a solar driven absorption cooling system with various collector types. Applied Thermal Engineering. 102, 749-59.

Bellos, E., Tzivanidis, C., Symeou, C.,Antonopoulos, K. A., 2017. Energetic, exergetic and financial evaluation of a solar driven absorption chiller-A dynamic approach. Energy conversion and management. 137, 34-48.

Boubenia, A., Hafaifa, A., Kouzou, A., Mohammedi, K.,Becherif, M., 2017. Carbone dioxide capture and utilization in gas turbine plants via the integration of power to gas. Petroleum. 3(1), 127-37.

Buttler, A.,Spliethoff, H., 2018. Current status of water electrolysis for energy storage, grid balancing and sector coupling via power-to-gas and power-to-liquids: A review. Renewable and Sustainable Energy Reviews. 82, 2440-54.

Castaneda, M., Cano, A., Jurado, F., Sánchez, H.,Fernandez, L. M., 2013. Sizing optimization, dynamic modeling and energy management strategies of a stand-alone PV/hydrogen/battery-based hybrid system. International journal of hydrogen energy. 38(10), 3830-45.

Conti, J., Holtberg, P., Diefenderfer, J., LaRose, A., Turnure, J. T.,Westfall, L. (2016). International energy outlook 2016 with projections to 2040: USDOE Energy Information Administration (EIA), Washington, DC (United States ....

De Santoli, L., Basso, G. L.,Nastasi, B., 2017. The potential of hydrogen enriched natural gas deriving from power-to-gas option in building energy retrofitting. Energy and Buildings. 149, 424-36.

Dorotić, H., Doračić, B., Dobravec, V., Pukšec, T., Krajačić, G.,Duić, N., 2019. Integration of transport and energy sectors in island communities with $100 \%$ intermittent renewable energy sources. Renewable and Sustainable Energy Reviews. 99, 109-24.

García-García, I., Barrio, V.,Cambra, J., 2018. Power-to-Gas: Storing surplus electrical energy. Study of catalyst synthesis and operating conditions. International Journal of Hydrogen Energy. 43(37), 17737-47.

Ghaib, K.,Ben-Fares, F.-Z., 2018. Power-to-Methane: A state-of-the-art review. Renewable and Sustainable Energy Reviews. 81, 433-46.

Gholizadeh, N., Vahid-Pakdel, M.,Mohammadi-ivatloo, B., 2019. Enhancement of demand supply's security using power to gas technology in networked energy hubs. International Journal of Electrical Power \& Energy Systems. 109, 83-94. 
Gondal, I. A., 2019. Hydrogen integration in power-to-gas networks. International Journal of Hydrogen Energy. 44(3), 1803-15.

Guandalini, G., Robinius, M., Grube, T., Campanari, S.,Stolten, D., 2017. Long-term power-to-gas potential from wind and solar power: A country analysis for Italy. International Journal of Hydrogen Energy. 42(19), 13389-406.

laquaniello, G., Setini, S., Salladini, A.,De Falco, M., 2018. $\mathrm{CO}_{2}$ valorization through direct methanation of flue gas and renewable hydrogen: A technical and economic assessment. International Journal of Hydrogen Energy. 43(36), 17069-81.

Jamali, D. H.,Noorpoor, A., 2019. Optimization of a novel solar-based multi-generation system for waste heat recovery in a cement plant. Journal of Cleaner Production. 240, 117825.

Johnson, G. L., 2006. Wind energy systems. Citeseer

Justus, C. G., 1978. Winds and wind system performance. Research supported by the National Science Foundation and Energy Research and Development Administration. Philadelphia, Pa., Franklin Institute Press, 1978. $120 \mathrm{p}$.

Kirchbacher, F., Biegger, P., Miltner, M., Lehner, M.,Harasek, M., 2018. A new methanation and membrane based power-to-gas process for the direct integration of raw biogas-Feasability and comparison. Energy. 146, 34-46.

Kreuter, W.,Hofmann, H., 1998. Electrolysis: the important energy transformer in a world of sustainable energy. International Journal of Hydrogen Energy. 23(8), 661-66.

Lewandowska-Bernat, A.,Desideri, U., 2018. Opportunities of power-to-gas technology in different energy systems architectures. Applied energy. 228, 57-67.

Li, Z. X., Ehyaei, M. A., Kamran Kasmaei, H., Ahmadi, A.,Costa, V., 2019. Thermodynamic modeling of a novel solar powered quad generation system to meet electrical and thermal loads of residential building and syngas production. Energy Conversion and Management. 199, 111982.

Lisbona, P., Frate, G. F., Bailera, M.,Desideri, U., 2018. Power-to-Gas: Analysis of potential decarbonization of Spanish electrical system in long-term prospective. Energy. 159, 656-68.

Llera, E., Romeo, L., Bailera, M., Osorio, J., Ebro, C. R.,de Luna, M., 2018. Exploring the integration of the power to gas technologies and the sustainable transport. Towards Energy Sustain. 77.

Miao, B.,Chan, S. H., 2019. The economic feasibility study of a 100-MW Power-to-Gas plant. International Journal of Hydrogen Energy.

Mozafari, A.,Ehyaei, M. A., 2012. Effects of Regeneration Heat Exchanger on Entropy, Electricity Cost, and Environmental Pollution Produced by Micro Gas Turbine System. International Journal of Green Energy. 9(1), 51-70.

Nakomčić-smaragdakis, B. B.,Dragutinović, N. G., 2016. HYBRID RENEWABLE ENERGY SYSTEM APPLICATION FOR ELECTRICITY AND HEAT SUPPLY OF A RESIDENTIAL BUILDING. Thermal Science. 20(2).

Pierrot, M., 2019. The wind power database. See www.thewindpower.net.

Powell, W. R., 1981. An analytical expression for the average output power of a wind machine. Solar Energy. 26(1), 77-80.

Roadmap, E. (2011). Mapping renewable energy pathways towards 2020: EREC.

Schaaf, T., Grünig, J., Schuster, M. R., Rothenfluh, T.,Orth, A., 2014. Methanation of $\mathrm{CO}_{2}$-storage of renewable energy in a gas distribution system. Energy, Sustainability and Society. 4(1), 2.

Shaygan, M., Ehyaei, M. A., Ahmadi, A., Assad, M. E. H.,Silveira, J. L., 2019. Energy, exergy, advanced exergy and economic analyses of hybrid polymer electrolyte membrane (PEM) fuel cell and photovoltaic cells to produce hydrogen and electricity. Journal of Cleaner Production. 234, 108293. 
Shirmohammadi, R., Soltanieh, M.,Romeo, L. M., 2018. Thermoeconomic analysis and optimization of post-combustion $\mathrm{CO} 2$ recovery unit utilizing absorption refrigeration system for a natural-gasfired power plant. Environmental Progress \& Sustainable Energy. 37(3), 1075-84.

Suresh, M., Reddy, K.,Kolar, A., 2012. Thermodynamic analysis of a coal-fired power plant repowered with pressurized pulverized coal combustion. Proceedings of the Institution of Mechanical Engineers, Part A: Journal of Power and Energy. 226(1), 5-16.

Thema, M., Bauer, F.,Sterner, M., 2019. Power-to-Gas: Electrolysis and methanation status review. Renewable and Sustainable Energy Reviews. 112, 775-87.

Tijani, A. S., Yusup, N. A. B.,Rahim, A. H. A., 2014. Mathematical Modelling and Simulation Analysis of Advanced Alkaline Electrolyzer System for Hydrogen Production. Procedia Technology. 15, 798806.

Toro, C.,Sciubba, E., 2018. Sabatier based power-to-gas system: Heat exchange network design and thermoeconomic analysis. Applied energy. 229, 1181-90.

Tzivanidis, C., Bellos, E.,Antonopoulos, K. A., 2016. Energetic and financial investigation of a stand-alone solar-thermal Organic Rankine Cycle power plant. Energy conversion and management. 126, 421-33.

Ulleberg, $\varnothing ., 2003$. Modeling of advanced alkaline electrolyzers: a system simulation approach. International Journal of Hydrogen Energy. 28(1), 21-33.

Verma, A., Singh, T.,Monjezi, M., 2010. Intelligent prediction of heating value of coal. Iranian Journal of Earth Sciences. 2, 32-38.

Walker, S. B., van Lanen, D., Mukherjee, U.,Fowler, M., 2017. Greenhouse gas emissions reductions from applications of Power-to-Gas in power generation. Sustainable Energy Technologies and Assessments. 20, 25-32.

Weidner, S., Faltenbacher, M., François, I., Thomas, D., Skùlason, J.,Maggi, C., 2018. Feasibility study of large scale hydrogen power-to-gas applications and cost of the systems evolving with scaling up in Germany, Belgium and Iceland. International Journal of Hydrogen Energy. 43(33), 15625-38.

Wulf, C., Linßen, J.,Zapp, P., 2018. Review of power-to-gas projects in Europe. Energy Procedia. 155, 367-78.

Yang, Y., Guo, S., Liu, D., Li, R.,Chu, Y., 2018. Operation optimization strategy for wind-concentrated solar power hybrid power generation system. Energy conversion and management. 160, 243-50. 


\section{Research highlights}

- A novel configuration of coal-fired cogeneration hybrid plant is proposed

- The system is powered by both the coal combustion chamber and wind turbines

- The process uses wind energy and co-produces electricity, cooling load and syngas

- $\mathrm{CO}_{2}$ emissions in exhaust gas are reduced by conversion to syngas in methanation unit

- Energy, exergy and economic analyses of this hybrid generation system are performed 


\section{Author contribution section}

The contribution of all authors for the paper entitled" Energy, exergy and economic analyses of new coal-fired cogeneration hybrid plant with wind energy resource

are the same.

\section{Corresponding author}

M.A.Ehyaei 


\section{Declaration of interests}

$\bigotimes$ The authors declare that they have no known competing financial interests or personal relationships that could have appeared to influence the work reported in this paper.

$\square$ The authors declare the following financial interests/personal relationships which may be considered as potential competing interests:

\section{M.A.Ehyaei}

Corresponding author 